No 2007 - 06

May

\title{
Specialisation across Varieties within Products and North-South Competition
}

Lionel Fontagné, Guillaume Gaulier \& Soledad Zignago

Paper presented at the 45th Panel Meeting of Economic Policy in Frankfurt 


\section{Specialisation across Varieties within Products and North-South Competition}

Lionel Fontagné, Guillaume Gaulier \& Soledad Zignago

No $2007-06$

May 


\section{TABLE OF CONTENTS}

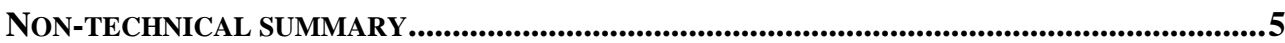

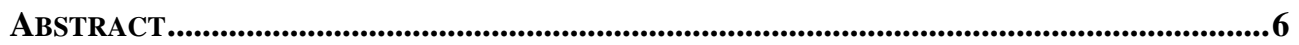

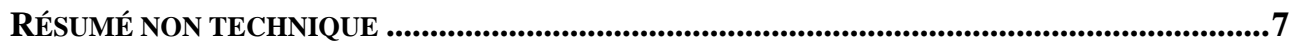

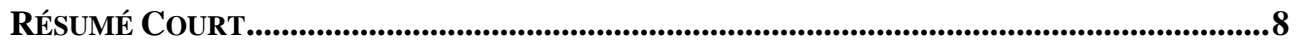

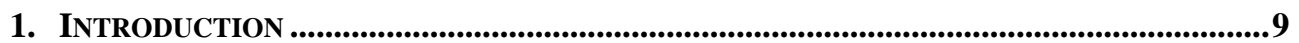

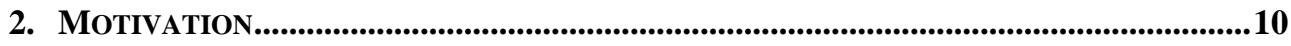

2.1. Similarity between North and South is a matter of aggregation level ..................12

2.2. Patterns of the destination market matter .......................................................... 15

3. Policy QUESTIONS.............................................................................................................16

3.1. Predictions of trade theory contradict with empirical evidence............................ 16

3.2. Empirical evidence sheds new light on North-South competition.........................17

3.3. Recent shifts in market shares concentrated in the low segment of the

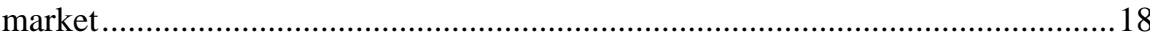

3.4. Competition in high tech sectors is exhibiting the same patterns ........................20

4. DATA DESCRIPTION AND CLASSSIFICATION OF VARIETIES INTO THREE MARKET

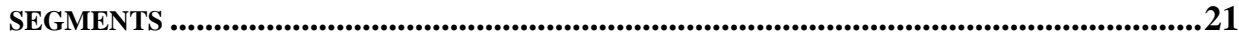

4.1. A world-wide database at the most detailed level of the product

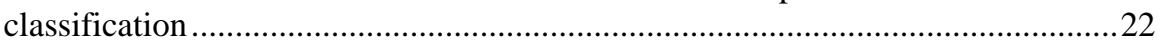

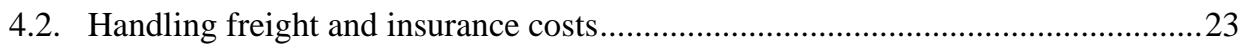

4.3. Allocating varieties shipped to market segments..............................................24

5. LIMITED SIMILARITY AMONG VARIETIES OF PRODUCTS JOINTLY EXPORTED BY

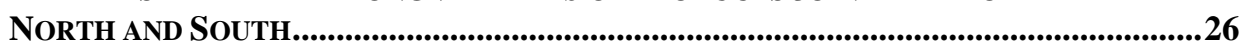

5.1. North and South export different varieties of the same products ........................26

5.2. Determinants of the market positioning of varieties .........................................29

6. SUPPLY AND DEMAND DETERMINANTS OF TRADE IN VARIETIES .................................31

6.1. A gravity equation accounting for the market positioning of varieties and

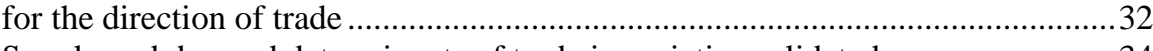

6.2. Supply and demand determinants of trade in varieties validated...........................34

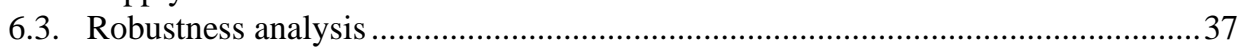




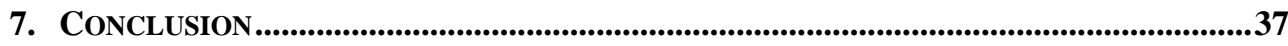

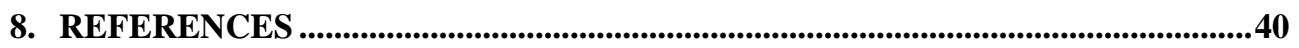

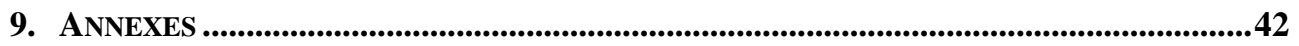

Appendix 1: Results with constant shares for market segments .....................................42

Appendix 2: Similarity of export structures at the transformation level (within

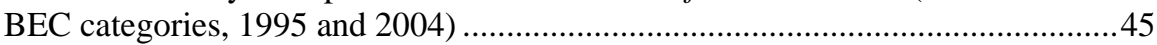

Appendix 3: The CEPII list of emerging countries .....................................................46

Appendix 4: Explaining bilateral exports in a panel of 163 countries and 10 years

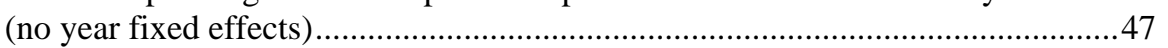

Appendix 5: Distribution of the median elasticity of export prices to GDP per capita of the exporting country (EU imports, 1995 to 2004, Member states

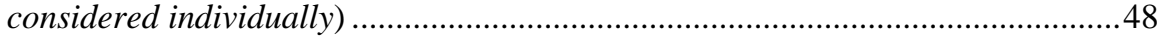

Appendix 6: Distribution of the median elasticity of export prices to GDP per capita of the exporting country ...................................................................................49

LIST OF WORKING PAPERS RELEASED BY CEPII ...................................................................51 


\section{SPECIALISATION ACROSS VARIETIES WITHIN PRODUCTS AND NORTH-SOUTH COMPETITION}

\section{NON-TECHNICAL SUMMARY}

Recent developments in trade theory and related empirical studies have drawn a revised picture of trade patterns that is refreshing our understanding of North-South competition: international specialisation has been proved to take place within products, across varieties, rather than across products or across industries. On average, Japanese unit values (values/quantities) for instance are 1.4 times higher than for Brazil, 1.9 times higher than for India, and 2.9 times higher than for China, for the same products, shipped to the same markets, within the same year (2004). Systematising this repeated empirical evidence, we ask here what are the precise patterns regarding the specialisation of countries within products and across varieties and what are the determinants of such specialisation. Better understanding such trade patterns helps to clarify the challenges for policy posed by the emergence of competitors in the South, covering the whole range of traded products.

Our value added is twofold. Firstly, we use BACI, the new CEPII data base of world trade covering the largest available set of countries over a decade at the most detailed level of the product classification. BACI reconciles the declarations of trading partners to the United Nations (COMTRADE), extracting trade costs from unit values of imports, and correcting for the quality of the declarations. We consider varieties of products inside each heading of the 6-digit level of the harmonised nomenclature, which comprises some 5,000 products. Secondly, we take advantage of this extensive coverage to systematically address the determinants of specialisation using a 10 year panel of 163 countries and 25 manufactured sectors. The latter exercise, thanks to the presence of developed and developing importers in the data set, enables us to separately identify the role of quality in North-North, NorthSouth, South-North and South-South trade relationships.

Our results point to four stylised facts. Firstly, the similarity of exports between North and South is much more limited when we consider differentiated varieties than when industries are considered. Secondly, and this generalises Schott's (2004) findings, the unit value (value divided by quantity) of exported products to a certain market varies with the level of development of the exporter. Thirdly, and according to the role played by traditional determinants of specialisation now operating across varieties, the observed redistribution of market shares at the world level has been especially detrimental to advanced economies for low unit value varieties, while the EU has better resisted competition in high unit value varieties, in particular in consumer goods. Fourthly, we use a gravity equation controlling for the supply and demand side determinants considered in the literature to explain the bilateral trade in varieties among developing and developed economies. 
On the basis of such detailed and systematic empirical evidence regarding the specialisation of countries within - rather than between - products, we ask whether the fears raised by North-South competition are exaggerated. China may be exporting under quite as much product headings as Germany, but at the most detailed level of the international classification of products, varieties exported by Germany and China are not in direct competition since their prices are too different. And if workers in the North and the South hardly compete on the same varieties, the link between trade and factor prices is somehow weakened. Our analysis confirms that advanced economies are keeping an advantage, or are suffering a lesser disadvantage, in the upper market segment. The bottom line of this reasoning is that North and South are not competing head on within industries; However such a conclusion should not hide the plausible domestic impacts of a systematic repositioning on up market varieties by advanced economies.

\begin{abstract}
There has been repeated evidence in the trade literature that international specialisation is taking place within products, across varieties, rather than across products or across industries. Using a new database which draws on United Nations COMTRADE data covering trade between 1995 and 2004 for more than 200 countries and 5,000 products, we systematise this evidence and ask what are the precise patterns and determinants of such specialisation between North and South. Although the two groupings of countries are quite similar when specialisation is considered across broadly defined sectors, they are very dissimilar when the differentiation of products, reflected in differences in unit values across varieties, is taken into account. We systematise Schott's relation between the unit values of varieties shipped and the level of development of the exporter. Lastly, we use a gravity equation accounting for the market positioning of varieties and for the direction of trade in order to shed light on the determinants of trade in varieties. We observe that supply and demand related determinants contemplated in the literature offer a coherent framework in which Linder's hypothesis combines with factor endowments. Overall, our analysis confirms that advanced economies are maintaining their advantage in the upper segment of product markets: North and South are not competing head on within industries. However, this conclusion does not exclude a likely impact on the advanced economies' labour markets of a systematic repositioning on up-market varieties.
\end{abstract}

\title{
JEL Classification: F1, F4
}

Keywords: $\quad$ Product Trade; Export Unit Values, Vertical Differentiation 


\section{SPÉCIALISATION SUR LES VARIÉTÉS DE PRODUITS ET CONCURRENCE NORD-SUD}

\section{RESUME NON TECHNIQUE}

La littérature théorique et empirique récente en commerce international a débouché sur une compréhension rénovée des spécialisations et de la concurrence Nord-Sud. La spécialisation se fait au niveau des variétés, non à celui des produits ou a fortiori des secteurs. Le fait que, en moyenne, sur un même marché et pour un même produit, les valeurs unitaires (valeurs sur quantités) japonaises par exemple soient,,1,4 fois plus élevées que les brésiliennes, 1,9 fois plus que les indiennes et 2,9 fois plus que les chinoises indique que les variétés exportées par ces différents pays ne sont pas identiques. Systématisant cette observation, nous nous intéressons aux caractéristiques précises - et aux déterminants - de la spécialisation des pays sur des variétés différenciées de produits. Une meilleure compréhension de cette nouvelle forme de spécialisation permet de clarifier les défis posés en termes de politique économique par l'émergence de concurrents du Sud exportant la grande majorité des produits.

Notre apport est double. Premièrement, nous utilisons BACI, la nouvelle base de données de commerce international du CEPII, couvrant un maximum de pays, de 1995 à 2004, au niveau le plus fin de détail sectoriel (5000 produits du Système harmonisé à 6 digits). En effet, afin d'avoir la plus la plus large couverture possible les données déclarées par les pays aux Nations Unies (COMTRADE) sont harmonisées : les flux d'importation sont calculés hors coûts de transport et confrontés aux déclarations de flux d'exportation correspondant, les écarts existants étant traités suivant la qualité des déclarations. Les valeurs unitaires harmonisées de BACI nous permettent de classer les flux bilatéraux en trois gammes de prix (variétés). Deuxièmement, sa couverture très large permet d'examiner de façon systématique les déterminants de la spécialisation des pays, en utilisant un panel de 10 ans, 163 pays et 25 industries manufacturières. On peut alors identifier le rôle distinct de la qualité dans le commerce Nord-Sud.

Nous mettons en évidence quatre types de résultats. Premièrement, nous montrons que la similarité des exportations entre le Sud et le Nord se réduit avec le niveau de détail sectoriel. Deuxièmement, nous confirmons sur une base mondiale la relation positive entre les valeurs unitaires des échanges et les niveaux de développement des exportateurs mise en évidence par Schott (2004). Troisièmement, et conformément à un schéma de spécialisation portant sur les variétés plutôt que sur les produits, nous observons que la redistribution des parts de marché au niveau mondial a été spécialement favorable au Sud pour les variétés à valeur unitaire basse, et que l'UE a mieux résisté que les autres zones développées dans celles à valeur unitaire élevée, en particulier les biens de consommation. Enfin, pour expliquer les échanges bilatéraux de variétés entre pays développés et en développement, nous utilisons une équation de gravité prenant en compte les déterminants en termes d'offre et de demande évoqués dans la littérature. 
Nos résultats montrent que les craintes suscitées par l'émergence du Sud pourraient être exagérées. Si, le nombre de produits exportés par la Chine, par exemple, a beaucoup augmenté pour atteindre pratiquement le niveau de l'Allemagne, les variétés de produits exportées par les deux pays ne sont pas en concurrence directe puisque les gammes de prix sont très différentes. Notre analyse confirme que les économies avancées conservent un avantage, ou souffrent d'un moindre désavantage, dans le segment du marché à valeurs unitaires élevées. Leur spécialisation sur le haut de gamme peut toutefois avoir des effets sur leurs marchés du travail.

\section{RESUME COURT}

La littérature empirique en commerce international a souligné à de nombreuses reprises que les pays se spécialisent sur les variétés d'un même produit, plutôt que sur les produits ou les industries. Utilisant BACI, la nouvelle base de données de commerce international du CEPII, fondée sur les données COMTRADE des Nations Unies et couvrant la période 1995-2004 pour plus de 200 pays et 5000 produits, nous systématisons cette observation et examinons les caractéristiques et déterminants de cette nouvelle forme de spécialisation Nord-Sud. Si les spécialisations des pays du Nord et du Sud peuvent sembler similaires à un niveau relativement agrégé de détail sectoriel, elles se révèlent très différentes lorsque l'on considère les différents segments de prix auxquels les produits sont vendus sur les différents marchés. Nous confirmons ainsi, sur une base mondiale, la relation positive entre valeurs unitaires des échanges et niveaux de développement des exportateurs mise en évidence par Schott (2004). Nous prolongeons cette analyse en estimant une équation de gravité qui prend en compte le positionnement par gamme des variétés échangées et la direction des échanges. Si nos résultats montrent que le Nord et le Sud ne sont pas en concurrence frontale sur les variétés, cela n'exclut pas un impact probable sur le marché du travail en raison du repositionnement sur le haut de gamme des producteurs du Nord.

Classement JEL : $\quad \mathrm{F} 1, \mathrm{~F} 4$

Mots Clés : $\quad$ Commerce de variétés, Valeurs unitaires des exportations, Différenciation verticale 


\title{
SPECIALISATION ACROSS VARIETIES WITHIN PRODUCTS AND NORTH-SOUTH COMPETITION
}

\author{
Lionel Fontagné, Guillaume Gaulier \& Soledad Zignago ${ }^{1}$
}

\section{INTRODUCTION}

Recent developments in trade theory and related empirical studies have drawn a revised picture of trade patterns that is refreshing our understanding of North-South competition.

Firstly, the fragmentation of the value added chain leads to a vertical specialisation of countries, and to an increasing share of trade in intermediate products used as inputs by downstream producers (Hummels et al., 2003, Naghavi and Ottaviano, 2006).

Secondly, the growing importance of Intra-Industry Trade (IIT), i.e. two-way trade within product categories, has been extensively documented using detailed trade data. It quickly became clear that IIT mainly consists of two-way trade in varieties differentiated by their positioning on the quality ladder (e.g. Greenaway et al., 1995, Fontagné et al., 2006). Ultimately, this led to a reassessment of the European experience of trade integration with countries at a different level of development: European integration led to another kind of specialisation, which hardly matched the standard view of inter versus intra-industry trade determinants (Fontagné et al., 1998, Diaz Mora, 2002).

Thirdly, and more generally, international specialisation has been proved to take place within products, across varieties, rather than across products or across industries. Since the pioneering work of Finger (1975) identified a larger variability of factor intensities within industries than across industries, a series of contributions have repeatedly addressed this stylised fact. Torstensson (1991) provides evidence of Sweden's specialisation on quality vis-à-vis countries at different levels of per capita income. But the major breakthrough is Schott's (2004) findings that US imports are exhibiting a large variance in unit values within product categories. This seminal paper has launched a new series of work on the actual patterns of trade specialisation. The International Monetary Fund, taking stock of the increasing world market shares of eight Central and Eastern European Countries, in spite of an appreciation of their real exchange rate, invoke an upgrading of the quality of exported varieties (IMF, 2006). Lastly, using 1995 import data for 59 countries from 110 exporters at the 6 digit level of the harmonised classification of traded goods, as well as 10 digit data on US imports, Hummels and Klenow (2005), find that large countries do export higher

\footnotetext{
${ }^{1}$ CEPII. Corresponding author: Lionel Fontagné, Panthéon Sorbonne Economie, Université Paris 1, Paris School of Economics and CEPII (lionel.fontagne@univ-paris1.fr).

We acknowledge helpful comments and suggestions by three anonymous referees on an earlier draft, and from Louise Curran on this draft. We also thank Rodrigo Paillacar, Dieudonné Sondjo and Adja Sissoko for their excellent research assistance in the latest stages of this draft. We thank participants to the seminar held at the INSEE for their suggestions.
} 
quality goods (the "quality margin" that may be interpreted as one component of the intensive margin), and not only more varieties (the extensive margin).

Systematising this repeated empirical evidence, we ask here what are the precise patterns regarding the specialisation of countries within products and across varieties and what are the determinants of such specialisation. Better understanding such trade patterns helps to clarify the challenges for policy posed by the emergence of competitors in the South covering the whole range of traded products.

Our value added is twofold. Firstly, we use a new data base covering the largest available set of countries over a decade. However, detailed trade data is often of limited reliability. Accordingly, in addition to such wide coverage, our data reconciles the declarations of trading partners, extracting trade costs from unit values of imports, and correcting for the quality of the declarations. Such extensive coverage comes however at a price: we use more aggregated data, as compared to Schott (2004). We consider varieties of products inside each heading of the 6-digit level of the harmonised nomenclature, which comprises some 5,000 products, while Schott relies on US data (resp. HS-10). The number of digits should not be interpreted too directly anyway: very often, the margin of detail offered by the larger number of digits is little, or incompletely used in trade statistics. ${ }^{2}$ Secondly we take advantage of this extensive coverage to systematically address the determinants of specialisation using a 10 year panel of 163 countries and 25 manufactured sectors. The latter exercise, thanks to the presence of developed and developing importers in the data set, enables us to separately identify the role of quality in North-North, North-South, SouthNorth and South-South trade relationships.

The remainder of the paper is organised as follows: the motivation for the paper is given in section 2. Policy questions raised by the evidence of international specialisation across varieties within products are discussed in section 3 . The original data set and the methodology used are presented in section 4. In section 5, we provide detailed empirical evidence on the limited similarity of varieties of the products exported by both developed and developing countries, which leads us in section 6 to identify the role of supply and demand determinants of trade in varieties. The last section concludes.

\section{Motivation}

A rather systematic finding of the trade literature is the considerable variation in unit values of traded products at the most detailed level of product classification. ${ }^{3}$ On average, Japanese unit values are 1.43 times higher than for Brazil, 1.86 times higher than for India, and 2.86 times higher than for China, for the same products, shipped to the same markets,

\footnotetext{
2 The HS6 distinguishes 5,100 different products, out of which 4,200 are manufactured products. This is to be compared with 16,380 products in 2001 for Schott.

Prices of traded products cannot directly be measured using trade statistics: they are proxied by unit values (values divided by quantities).
} 
within the same year (2004). Similarly, US export unit values are on average 1.58 times higher than for India and 2.44 times higher than for China. Such evidence is puzzling and raises a series of questions.

Let us split trade flows into three market segments (low, medium, high) defined by the unit values of the traded varieties. In Figure 1 we plot the share of down- and up-market varieties, in US imports from each exporter, by development level (GDP per capita relative to the US) of the latter. The size of the bubble is proportional to the value of US imports from each country. We observe a clear pattern. There is negative relationship between development level of the exporter to the US and its specialisation in down-market varieties; And reciprocally for up-market ones.

We can observe a similar pattern of Japanese imports in Figure 2.

Figure 1: Share of down- and up-market varieties, in US imports from each exporter, bydevelopment level (GDP per capita relative to the US) of the exporter.

Down-market

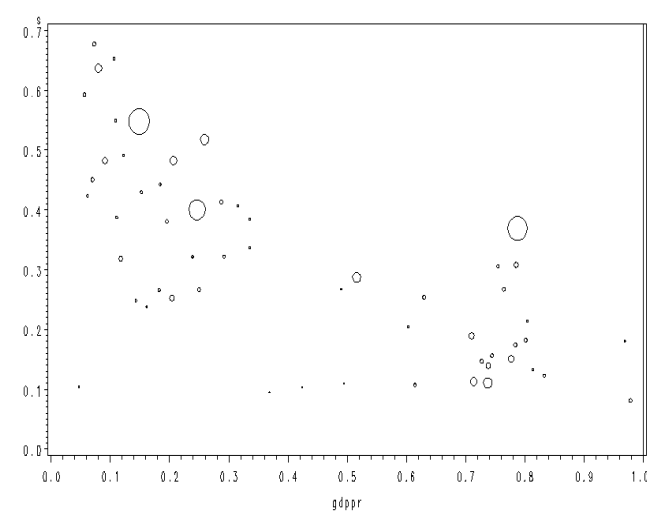

Up-market

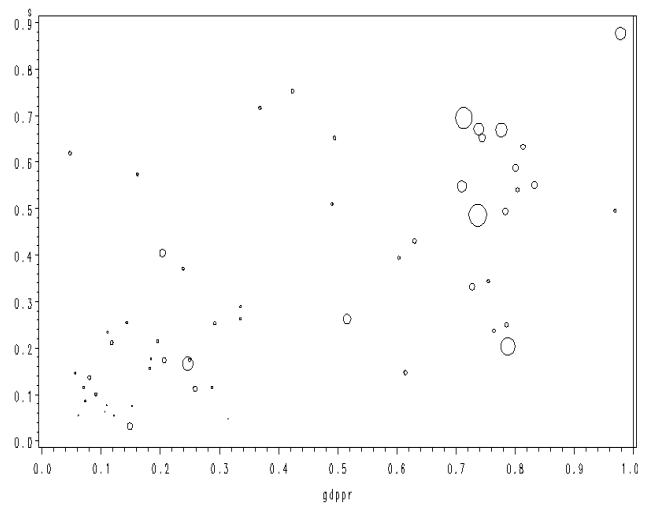

Note: Size of the bubble proportional to the value of US imports by origin country. Imports above USD 1 bn only. Source: BACI-CEPII. Authors' calculations. 
Figure 2: Share of down- and up-market varieties, in Japanese imports from each exporter, by development level (GDP per capita relative to Japan) of the exporter.

Down-market

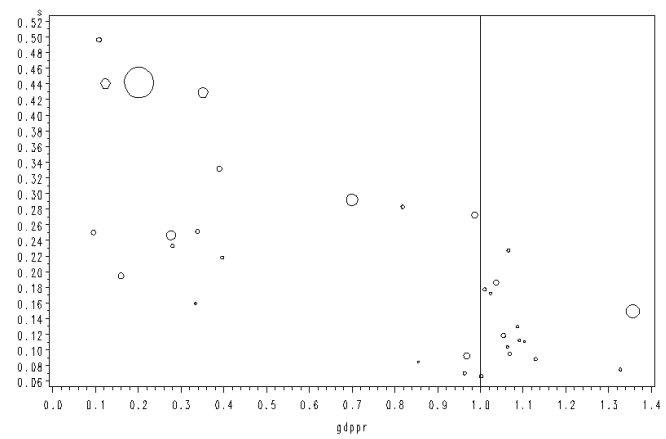

Up-market

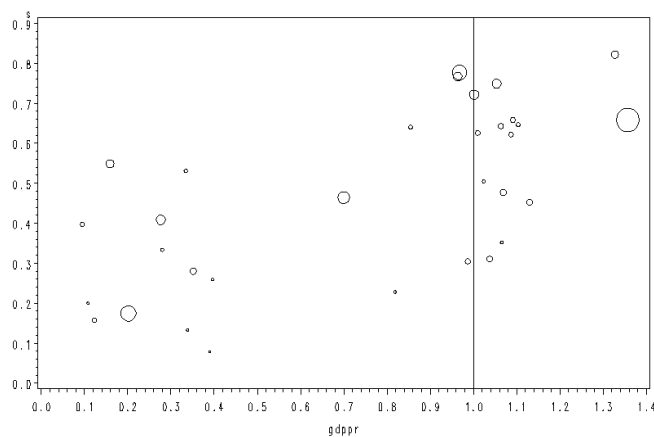

Note: Size of the bubble proportional to the value of Japanese imports by origin country. Imports above USD 1 bn only. Source: BACI-CEPII. Authors' calculations.

\subsection{Similarity between North and South is a matter of aggregation level}

To illustrate how exactly the international division of labour is taking place among countries at different levels of development, let us consider indicators of export similarity, computed alternatively at the level of "sector" (26 ISIC manufacturing industries), versus "product" (defined as an heading of the HS6), versus "varieties" (defined as exports shipped under the same HS6 heading at different prices) . "The similarity of export sectoral structures is the sum of the absolute value of differences between the sectoral (or product or variety) shares in manufacturing exports of each country.

\footnotetext{
${ }^{4}$ We rely here on the distinction proposed by Schott (2004) between products and varieties. Two varieties of a product will be classified under the same HS6 heading, but will have different unit values. This departs from the vocabulary of the literature on IIT, which uses "varieties" to refer to products shipped under the same HS6 heading but having similar unit values (horizontal differentiation), as opposed to "qualities" having different unit values (vertical differentiation).
} 
Considering similarity indexes computed at the sectoral level (Table 1), one might conclude that there is intensive competition between the North and the South. ${ }^{5}$ Although, similarity is especially high for pairs of countries in the North, like for example an index of 0.77 for the United States and Japan (1 is perfect similarity); More interestingly, values near or above 0.50 are obtained for North-South comparisons: the similarity between China and the United States or Japan is comparable to the similarity between China and India.

Table 1: Similarity of export structures at the sector level (within ISIC categories, 2004)

\begin{tabular}{lrrrrrrrr}
\hline \hline & Brazil & China & Japan & Russia & India & USA & EU25 Oth. Em. \\
\hline Brazil &. & & & & & & & \\
China & 0.39 &. & & & & & & \\
Japan & 0.52 & 0.56 &. & & & & & \\
Russia & 0.54 & 0.30 & 0.37 &. & & & & \\
India & 0.50 & 0.56 & 0.38 & 0.48 &. & & & \\
USA & 0.59 & 0.55 & 0.77 & 0.48 & 0.48 &. & & \\
EU25 & 0.57 & 0.50 & 0.60 & 0.46 & 0.52 & 0.69 & & \\
Oth. Em. & 0.46 & 0.44 & 0.35 & 0.38 & 0.45 & 0.39 & 0.42 & 0.40 \\
\hline \hline
\end{tabular}

Note: Similarity between country A (column) and B (row) is the sum of the absolute value of differences between the sectoral (ISIC) shares in manufacturing exports of country A and those of country B. It ranges between 0 (perfect dissimilarity) and 1 (perfect similarity). The 'other emerging' group are defined as the emerging economies less Russia, India, China and Brazil. Any classification of countries is arbitrary. We stick here to CEPII's definition of emerging economies, based on the statistical criterion reproduced in Appendix 3. Note that new member states of the EU25 are not considered as emerging economies but simply as member states.

Source: BACI-CEPII. Authors’ calculations.

A similar calculation can be made at the most detailed level of the nomenclature, using a classification of manufactured products at the 6 digit level of the Harmonised nomenclature, instead of using ISIC industries (Table 2). The similarity indexes are much lower, indicating that North and South exporters are specialised on different products within industries. Still, sizeable similarity can be found not only within the Triad (EU25, Japan, USA), but even between China and Japan (0.34) or China and the United States (0.34).

\footnotetext{
5 Using a more aggregated classification of products, the Broad Economic Categories of the United Nations by transformation level, leads, not surprisingly, to an even greater level of similarity. In Appendix 2, results considering three stages of production (intermediate, consumption and investment) are reported for 1995 and 2004. The similarity peaks to 0.95 for the pair USA-Japan in 1995. More interestingly, the similarity between Chinese exports on the one hand, and EU, Japanese or US exports on the other, has very much increased in terms of transformation levels between 1995 and 2004. The share of intermediate, consumption or investment products in total exports is accordingly converging, which explains the increasing concerns of advanced economies' exporters, confronted with Chinese exporters in markets where there were not present a decade ago.
} 
Table 2: Similarity of export structures at the product level (2004)

\begin{tabular}{lrrrrrrrr}
\hline \hline & Brazil & China & Japan & Russia & India & USA & EU25 & Oth. Em. \\
\hline Brazil &. & & & & & & & \\
China & 0.22 &. & & & & & & \\
Japan & 0.29 & 0.34 &. & & & & & \\
Russia & 0.31 & 0.16 & 0.2 &. & & & & \\
India & 0.26 & 0.30 & 0.23 & 0.21 &. & & & \\
USA & 0.32 & 0.34 & 0.53 & 0.26 & 0.27 &. & & \\
EU25 & 0.26 & 0.25 & 0.31 & 0.21 & 0.24 & 0.37 & & \\
Oth. Em. & 0.18 & 0.23 & 0.17 & 0.14 & 0.20 & 0.19 & 0.18 & 0.18 \\
\hline \hline
\end{tabular}

Note: See Table 4.

Source: BACI-CEPII. Authors’ calculations.

Lastly, if we consider varieties of products, the similarities decrease again, especially for North-South pairs (Table 3). Industrialised countries are not competing with emerging countries (or with each other to a lesser extent) on the same varieties, thanks to a clear specialisation within product categories. When China and Triad countries export the same products, Chinese varieties are usually down-market, while Triad varieties are up-market. The similarity index between China and USA falls to 0.23 , and to 0.18 vis-à-vis Japan.

Table 3: Similarity of export structures at the variety level (2004)

\begin{tabular}{lrrrrrrrr}
\hline \hline & Brazil & China & Japan & Russia & India & USA & EU25 & Oth. Em. \\
\hline Brazil &. & & & & & & & \\
China & 0.16 &. & & & & & & \\
Japan & 0.22 & 0.18 &. & & & & & \\
Russia & 0.26 & 0.12 & 0.15 &. & & & & \\
India & 0.22 & 0.24 & 0.16 & 0.17 &. & & & \\
USA & 0.26 & 0.23 & 0.40 & 0.20 & 0.20 &. & & \\
EU25 & 0.19 & 0.15 & 0.25 & 0.16 & 0.20 & 0.29 & .14 \\
Oth. Em. & 0.15 & 0.16 & 0.13 & 0.12 & 0.19 & 0.15 & 0.14 & 0.14 \\
\hline \hline
\end{tabular}

Note: See Table 4.

Source: BACI-CEPII. Authors' calculations.

To summarise, when industries are considered, the similarity between Chinese and EU exports is high (similarity index is 0.50 ). When products within industries are considered, this similarity is divided by two (resp. 0.25). When varieties of these products, exported at different unit values are considered, the similarity is once again reduced (resp. 0.15). Accordingly, it appears that countries do not specialise across sectors or across products, they specialise within products across varieties. North and South countries can still look quite similar when their specialisation is considered across broadly defined sectors. This can still be the case considering products. However a strong dissimilarity is 
likely to emerge when the differentiation of products (as reflected by differences in unit values across varieties) is taken into account.

\subsection{Patterns of the destination market matter}

Such regularities are not determined only by the characteristics of the exporting country. The demand side of such empirical evidence must also be addressed. According to the Linder hypothesis (Linder, 1961; Hallak, 2006-a), there is a positive relationship between income level and demand for quality. Thus rich countries spend a larger share of their income on top quality products and import products of higher quality. Stylised facts are in accordance with this hypothesis. Table 4 presents the results of a bilateral calculation, indicating how much each exporter is selling in the upper tier of the market toward each destination.

Table 4: Share of up-market products in manufactured exports, by destination market (2004)

\begin{tabular}{lrrrrrrrrrrrr}
\hline \hline $\begin{array}{l}\text { Importer } \\
\text { Exporter }\end{array}$ & \multirow{2}{*}{ EU 25 } & \multirow{2}{*}{ USA } & \multicolumn{2}{c}{ Japan Oth. dev } & China & Brazil Russia & India Oth. Emerg. & RoW & Total \\
\hline EU 25 &. & 66.6 & 75.3 & 54.4 & 53.7 & 34.5 & 24.4 & 49.2 & 36.7 & 39.8 & 50.7 \\
USA & 58.5 &. & 67.5 & 36.4 & 42.7 & 26.3 & 25.8 & 49.1 & 14.7 & 32.6 & 39.6 \\
Japan & 58.6 & 49.1 &. & 48.4 & 45.2 & 35.3 & 7.5 & 46.1 & 31.4 & 21.6 & 45.9 \\
Oth. dev & 45.3 & 26.0 & 39.6 & 31.4 & 27.1 & 24.3 & 18.8 & 23.0 & 18.8 & 27.9 & 31.2 \\
China & 13.8 & 4.5 & 17.6 & 6.4 &. & 22.7 & 2.9 & 19.9 & 8.5 & 8.0 & 9.9 \\
Brazil & 25.8 & 17.5 & 33.9 & 17.1 & 15.4 &. & 2.2 & 12.3 & 11.2 & 15.8 & 17.6 \\
Russia & 8.9 & 17.6 & 13.3 & 9.7 & 14.3 & 16.5 &. & 38.6 & 7.0 & 11.1 & 11.5 \\
India & 20.0 & 13.6 & 19.7 & 12.5 & 10.8 & 16.3 & 9.4 &. & 17.4 & 16.1 & 16.2 \\
Oth.Emerg. & 36.6 & 18.8 & 34.8 & 24.8 & 24.0 & 28.3 & 9.0 & 27.1 & 20.7 & 19.6 & 25.3 \\
RoW & 31.1 & 17.3 & 29.7 & 18.2 & 6.1 & 28.6 & 9.2 & 14.3 & 13.5 & 18.1 & 21.3 \\
\hline Total & 39.6 & 33.8 & 43.2 & 35.2 & 36.7 & 29.2 & 18.5 & 32.0 & 22.3 & 29.1 & 33.6 \\
\hline \hline
\end{tabular}

Note: The sample covers manufacturing HS6 goods including the food industry. The parameter $\alpha$ that regulates the smoothness of the market segment allocation function (see sub-section 4.5 below) is put at 4 to have around the same value in average in each range for total trade in all products.

Source: BACI-CEPII, authors’ calculation.

Advanced countries do indeed export high unit values varieties. In 2004, Japan was shipping $45.9^{6}$ percent of its exports in varieties positioned in the upper segment. In contrast, China was shipping only 9.9 percent of its exports in the up-market segment in the same year.

${ }^{6}$ By the constant market shares of market segments, this share is reduced to 37.2 percent of total Japanese exports. 
On the demand side, we observe a clear difference in the market positioning of the various exporters on their different destination markets, stressing that importers at different levels of development do consume a different bundle of varieties. In 2004, 75.3 percent of European exports to Japan were up-market varieties, compared with only 53.7 percent to China.

\section{Policy QUeSTIONS}

The repeated evidence of specialisation across varieties within products, which is a key departure from the standard synthesis between classical and new trade theories, helps better understanding the important policy issues raised.

\subsection{Predictions of trade theory contradict with empirical evidence}

According to the standard theory of international trade, and using a multi-products setting, countries will not specialise in products exhibiting relative factor contents at odds with their relative endowments. Hence different countries should have different bundles of exported products. In contrast, the 'New' trade theory basically relies on trade in varieties having the same production function. In the latter framework using a single factor, countries advantaged in terms of productivity should ship low price varieties. This is the very framework synthesised by Helpman and Krugman (1985), where different countries specialise in different industries, while similar countries specialise in different varieties shipped at the same price. This framework has inspired the bulk of empirical studies in the literature addressing product variety on the basis of the combination of assumptions of a representative consumer, love of variety and horizontal differentiation.

Both predictions are conflicting with the repeated empirical evidence of trade in varieties at dissimilar prices among countries at different levels of development. This happens not only because intra-industry trade mainly consists of two-way trade in varieties with different unit values, but more interestingly because countries advantaged in terms of productivity do not export low price but rather high price varieties. Another departure from the predictions of the Helpman-Krugman synthesis is the evidence that countries actually import only a subset of all available varieties, while all varieties should enter symmetrically in preferences.

In contrast with the horizontal differentiation literature, which excludes any role for differences in income in the explanation of trade patterns, large and systematic differences in unit values are observed at the most detailed level. In the case of US imports, these differences have been proved to be related to the factor endowments and development level of the exporting country (Schott, 2004). Contrary to the standard theory of trade, exporters to the US market do not specialise in a limited subset of products exhibiting production functions in coherence with their factor endowments, but on the contrary manage to

7 As stressed by Schott (2004), there is indeed a possibility that the most efficient producers compete on quality rather than on price, according to a quality ladder hypothesis, but this is not what the standard new trade theory approach à la Dixit-Stiglitz has put at the forefront of contemporary explanations of trade patterns. 
specialise in a wide range of products. China provides an illuminating example of a labour abundant country producing a wide range of traded products, at odds with the predictions of the standard trade theory, while receiving a low price for its exported varieties, in line with a specialisation within products (Schott, 2006). Hence, one is not facing an endowmentdriven specialisation across products, but on the contrary an endowment driven specialisation across varieties within products. This finding led Schott to suggest that "our thinking about international specialisation must shift away from industries (...) and toward varieties within industries (...)”.

Interpreting differences in unit values of varieties of the same product is rather challenging. Using detailed trade data, Hummels and Klenow (2005) point to the necessary differences in quality to explain such differences in unit values. There are accordingly explanations in terms of supply and demand of quality.

On the supply side, possible explanations of the positive relationship between unit values of exports and exporters' income per capita identified by Schott (2004) in the US case, would be the exploitation of the productivity advantage to specialise in top-range varieties (Melitz, 2000); Or more generally an old-fashion theoretical framework, where advantage is based on a combination of factor endowments and technological advance (e.g. Falvey and Kierzkowski, 1987).

On the demand side, rich countries trade more with each other, after controlling for intersectoral determinants of trade (Hallak, 2006-a and -b), in line with the Linder hypothesis. Flam and Helpman (1987) proposed a framework in which varieties of different qualities were produced at a cost reflected in higher prices for higher qualities. Marginal income is spent by the consumers on quality rather than on quantities. This model, extended by Choi et al (2006) to a multi-product, multi-country framework, allows for high-income countries buying high unit value varieties. However, even when countries have access to the same technology, the quality positioning of their specialisation will be determined by domestic conditions: the larger or the more sophisticated the domestic market, the higher the quality of products supplied to the local consumer (Motta et al. 1997).

\subsection{Empirical evidence sheds new light on North-South competition}

This shift in our understanding of international specialisation, based on the evidence of large differences in unit values of varieties should prevent us from drawing hasty conclusions on the competitive pressures faced by high income countries coping with competition from emerging economies. On the one hand, the North is now in competition with the South on a wide range of products. Nearly the whole spectrum of the HS6 headings are covered by Chinese exports, even if such a pattern would not be observed for non-emerging developing economies. Accordingly, one could fear direct competition between workers in the North and South on the whole range of products, inducing downward pressure on wages in the North. However if the varieties shipped by the North

${ }^{8}$ Schott (2004), p. 649. 
and the South are different (as suggested by their very different unit values), the risks of direct competition are consequently reduced.

Since workers in the North and in the South hardly compete on the same varieties, the link between trade and factor prices is somehow weakened (subject indeed to the degree of substitution between high and low quality goods). The empirical evidence at the HS6 level is that China was exporting 4,898 products out of 5,041 in 2004, compared with 4,932 products for Germany. Moreover, when one takes as a benchmark the number of pairs of destination market and exported products, China was exporting on 335,720 such “elementary markets” in 2004 (but only 163,250 in 1995), compared with 352,855 in 2004 for Germany. Although China may well export as many products as Germany at the most detailed level of the international classification of products, varieties exported by Germany and China are not in direct competition. As the next section shows, we face a situation where countries are completely specialised within products, on varieties with different market positioning. In terms of the traditional factor price equalisation mechanism, our results suggests that North and South are not directly competing and should smooth the perception of the impacts of globalisation. Such a conclusion must, however, be carefully qualified.

The need to climb the ladder of vertical differentiation of products may well profoundly impact on advanced economies. A first and obvious channel is that the production function of goods is accordingly changing. Instead of producing a consumption good with inputs of blue collar workers, capital and raw materials, what is needed now is a combination of highly skilled designers, market analysts, engineers, etc. Accordingly, such a shift in production technologies may well have a similar impact to biased technical progress, detrimental to low-skilled, less adaptable workers.

Such an argument sheds new light on the puzzle of the respective role of technical progress and international competition in the relative worsening of the position of unskilled labour in the North. This might not be the direct effect of the competition from the South, which is not the main culprit, but rather the indirect effect, through the impact on the labour market of the strategy of up market positioning adopted by firms in the North.

\subsection{Recent shifts in market shares concentrated in the low segment of the market}

The market positioning of exporters and the recent shift in world market shares confirm such diagnosis, in particular in the European case.

In the lower segment of the world market, the share of EU exporters was limited to 14.22 percent in 2004. This is to be compared with a 32.16 percent world market share in the upper segment. Such positioning was much less striking for the US economy: 11.52 percent in the upper segment and 14.97 percent in the lower market segment. Even for Japan such differences are less marked: 7.12 percent in the lower segment and 14.22 percent in the upper segment. In contrast, China had an impressive market share in the lower segment (20.55 percent of the world market), but six times less than that in the upper segment. Such 
differences in market positioning are more apparent for consumer goods, which have the potential to be highly differentiated, where the EU market share in the upper segment peaks to 38.69 percent, against 4.96 percent for China.

The redistribution of market shares by market segment and transformation level observed over the last decade, confirm that European producers have better resisted new competitive pressures in the upper segment, in particular for consumer goods (Table 5). The EU has conceded 2.93 percentage points of world market share in the lower segment, but has gained 3.91 percentage points in the upper segment. Japan and the US have lost ground on both market segments, while Chinese gains have been concentrated in the lower segment (11.26 percentage points, Table 6).

Table 5: World market shares by transformation level and market segment of manufactured products (intra-EU excluded, 2004, percent)

\begin{tabular}{|c|c|c|c|c|c|}
\hline $\begin{array}{l}\text { Market } \\
\text { segment }\end{array}$ & Exporter & $\begin{array}{r}\text { Intermediate } \\
\text { goods }\end{array}$ & $\begin{array}{r}\text { Consumer } \\
\text { goods }\end{array}$ & $\begin{array}{r}\text { Investment } \\
\text { goods }\end{array}$ & All \\
\hline \multirow{9}{*}{ Lower } & EU 25 & 14.05 & 12.62 & 16.27 & 14.22 \\
\hline & USA & 13.89 & 7.47 & 10.06 & 11.52 \\
\hline & Japan & 8.12 & 3.5 & 8.48 & 7.12 \\
\hline & Oth. devpd & 20.02 & 18.44 & 18.48 & 19.30 \\
\hline & China & 13.78 & 27.94 & 29.16 & 20.55 \\
\hline & BRI & 7.43 & 6.11 & 2.71 & 6.06 \\
\hline & Oth. Emerg. & 15.11 & 15.87 & 11.26 & 14.42 \\
\hline & RoW & 7.6 & 8.06 & 3.58 & 6.80 \\
\hline & All & 100.0 & 100.0 & 100.0 & 100 \\
\hline \multirow{9}{*}{ Upper } & EU 25 & 29.71 & 38.69 & 29.83 & 32.16 \\
\hline & USA & 15.17 & 10.04 & 19.8 & 14.97 \\
\hline & Japan & 16.14 & 11.9 & 16.98 & 15.22 \\
\hline & Oth. devpd & 21.07 & 13.82 & 18.74 & 18.52 \\
\hline & China & 2.49 & 4.96 & 3.39 & 3.38 \\
\hline & BRI & 2.08 & 2.08 & 1.69 & 1.98 \\
\hline & Others Em. & 10.07 & 13.45 & 7.68 & 10.37 \\
\hline & RoW & 3.27 & 5.08 & 1.89 & 3.41 \\
\hline & All & 100.0 & 100.0 & 100.0 & 100 \\
\hline
\end{tabular}

Note: BRI for Brazil, Russia, India.

Source: BACI, authors' calculation.

Such results must however be handled cautiously, since the share of each market segment at the world level can slightly change over time, as world prices change. If European producers gain market share in a segment that is shrinking as a result of reinforced competition, they might actually not gain in terms of actual trade. An alternative methodology, in which market segment shares are constant over time, must be used to check whether this has happened (explained in Section 4.3). In Table A5 of Appendix 1, we use a different criterion (based on percentiles) in order to allocate trade flows to market segments. The share of up-market products in world trade is constant, even if the average unit value of varieties shipped in this segment is going down. We now record a stability of 
the European market share in the upper segment (-0.02 percent over a decade), corresponding to gains in high-price consumption goods and losses in high-price investment goods. EU25 outperforms the US and Japan. The market share of the latter two countries is more adversely affected in both segments of the market. In total, whatever the definition of market segments chosen, the empirical evidence points to a resilience of EU producers in the upper segment, in particular for consumer goods.

Table 6: Changes in world market shares by transformation level and market segment of manufactured products (1995 to 2004, percentage points)

\begin{tabular}{llrrrr}
\hline \hline $\begin{array}{l}\text { Market } \\
\text { segment }\end{array}$ & Exporter & $\begin{array}{r}\text { Intermediate } \\
\text { goods }\end{array}$ & $\begin{array}{r}\text { Consumer } \\
\text { goods }\end{array}$ & $\begin{array}{r}\text { Investment } \\
\text { goods }\end{array}$ & All \\
\hline \multirow{5}{*}{ Lower } & EU 25 & -2.98 & -1.58 & -4.76 & -2.93 \\
& USA & -3.92 & -3.85 & -3.76 & -3.84 \\
& Japan & -3.08 & 0.52 & -7.42 & -2.99 \\
& Oth. devpd & -2.59 & -6.67 & -6.04 & -4.33 \\
& China & 8.69 & 8.23 & 21.44 & 11.26 \\
& BRI & 1.30 & 2.25 & 0.98 & 1.40 \\
& Others Em. & 1.53 & -0.51 & -1.80 & 0.25 \\
& RoW & 1.05 & 1.62 & 1.37 & 1.17 \\
& All & 0.00 & 0.00 & 0.00 & 0.00 \\
\hline \multirow{4}{*}{ Upper } & Upper & Intermediate & Consumer & Investment & All \\
& EU 25 & goods & goods & goods & 3.91 \\
& USA & 2.62 & 6.26 & 3.51 & -2.69 \\
& Japan & -2.53 & -1.00 & -4.23 & -5.63 \\
& Oth. devpd & -5.23 & -4.03 & -7.69 & -1.25 \\
& China & -0.28 & -3.22 & -0.78 & 1.31 \\
& BRI & 1.38 & -0.44 & 2.81 & 0.35 \\
& Others Em. & -0.15 & 1.18 & 2.76 \\
& RoW & 2.72 & 1.19 & 4.13 & 1.24 \\
& All & 1.15 & 1.42 & 1.07 & 0.00 \\
\hline \hline
\end{tabular}

Note: BRI for Brazil, Russia, India.

Source: BACI, authors’ calculation.

\subsection{Competition in high tech sectors is exhibiting the same patterns}

The technological sector, once seen as a safe haven for developed countries, seems to be increasingly contested by emerging countries. Using the, now standard, view of international trade where countries compete in terms of technological leadership and extract rents, it is worth isolating hi-tech products in our data. This can be done at the product 
(rather than sector) level using the OECD-Eurostat classification ${ }^{9}$. We focus on products belonging to this list and ask what is the market positioning of technological products exported by the North and the South and how market shares have changed over the last decade.

Table 7 sheds light on how market shares have changed for the upper and lower market segments, for standard versus high-tech products. Focusing on the latter products, the better resilience of Europe to competition, as compared to Japan or the US, is confirmed, as is fact that Europe's performance is relatively better in the upper segment. China has dramatically increased its market share for hi-tech products in the last decade, but Chinese gains are concentrated in the lower segment of the market.

As previously stressed, it is worth checking that our conclusion is robust with a different definition of market segments. This is done in Table A7 of Appendix 1. The main message is unaffected by such a shift in the methodology: Europe better resists competition, in particular in the upper segment. However, in this approach, the EU is losing ground even in the upper segment of hi-tech products ( -2.40 percentage points). How to reconcile this result with the previously mentioned stability of the European market share for products taken as a whole is straightforward: we can check in Table A10 that the EU gained market share for standard products and lost market share for hi-tech products in the upper segment of the market. This is perfectly coherent with greater European resilience in high price consumer goods.

\section{DATA DESCRIPTION AND CLASSSIFICATION OF VARIETIES INTO THREE MARKET SEGMENTS}

In order to exhaustively measure the market positioning of exporters of the North and the South, on their different markets, we use a newly developed database of world trade flows: BACI. ${ }^{10}$ Relying on this exhaustive set of exporters and importers, we address differences in relative unit values between the North and the South for the same products. These unit values are used to calculate price ratios of varieties exported, as well as to allocate varieties shipped to the different market segments.

\footnotetext{
This list permits us to create a dummy at the HS6 level: accordingly, a product is either "hi-tech" or "standard" and all varieties of a "hi-tech product", whatever the market segment they belong to, are "hitech".

10 BACI is the French acronym for "Base pour l'Analyse du Commerce International": Database for International Trade Analysis. See http://www.cepii.fr/anglaisgraph/bdd/baci.htm.
} 
Table 7: World market shares (intra-EU excluded) for standard and hi-tech manufactured goods, by market segment (1995 and 2004, percent)

\begin{tabular}{lrrrr}
\hline \hline & & Standard goods & \multicolumn{2}{c}{ HT goods } \\
\hline Exporter & down-mk & up-mk & down-mk & up-mk \\
\hline EU 25 & & & $\mathbf{1 9 9 5}$ & \\
USA & 17.00 & 28.66 & 18.21 & 25.78 \\
Japan & 14.67 & 16.13 & 20.17 & 26.80 \\
Oth. Dev & 9.36 & 20.62 & 15.42 & 22.18 \\
China & 23.90 & 20.05 & 21.73 & 18.13 \\
BRI & 9.61 & 2.34 & 7.03 & 0.45 \\
Oth. Em. & 5.12 & 1.83 & 1.39 & 0.46 \\
RoW & 14.11 & 8.03 & 14.57 & 5.06 \\
All & 6.22 & 2.34 & 1.48 & 1.13 \\
Exporter & 100 & 100 & 100 & 100 \\
\hline EU 25 & & & $\mathbf{2 0 0 4}$ & \\
USA & 14.02 & 33.31 & 15.28 & 26.82 \\
Japan & 10.89 & 13.79 & 14.99 & 20.41 \\
Oth. Dev & 6.83 & 15.41 & 8.70 & 14.30 \\
China & 19.51 & 17.61 & 18.19 & 22.77 \\
BRI & 19.53 & 3.41 & 26.15 & 3.25 \\
Oth. Em. & 6.71 & 2.08 & 2.52 & 1.49 \\
RoW & 14.81 & 10.62 & 12.28 & 9.22 \\
All & 7.7 & 3.77 & 100 & 1.74 \\
\hline \hline
\end{tabular}

Note: See Table 1. High Tech goods are identified at the most detailed level by the Eurostat-OECD list. Source: BACI-CEPII, authors' calculation.

\subsection{A world-wide database at the most detailed level of the product classification}

BACI draws on United Nations COMTRADE data and covers trade for more than 200 countries and 5,000 products, between 1995 and 2004. In the following, only manufactured products will be considered; Intra-EU trade flows will be excluded.

Imports and exports flows are reported annually by 140 countries to United Nations in values and quantities at the HS6 level. New procedures have been developed in order to provide a more disaggregated and rigorous trade database for the largest possible number of countries and years, with special care given to the treatment of unit values.

${ }^{11}$ We use here data starting in 1995. The first declarations in HS appear in 1989, but the current version of BACI reaches a very broad world coverage in 1995. More precisely, BACI in HS from 1992 covers the period 1994-2005 and BACI in the HS from 1996 the period 1996-2005. Since 86 percent of quantities are declared in tons, the other quantities are then converted into tons by a rate of conversion estimated by product using mirror flows reported in tons by a country and in another unit (units, watt, meter, etc.) by the other trade partner. 
When only one country reports the observed flow, there is no way of assessing the quality of this specific record. When both the exporting and the importing country report, we have two figures for the same flow, which have to be reconciled given the, often huge, discrepancies between them. An evaluation of the reliability of country declarations is then used as a weighting for the average of mirror values, unit-values and quantities.

In order to evaluate the reliability of countries reporting (as exporters or importers) we decompose the absolute value of the ratios of mirror flows using a (weighted) variance analysis. The error variable (absolute value of the natural log of the ratio of mirror flows) is regressed on four sets of fixed effects concerning exporters, importers, products and years. The OLS estimator is used, each trade flow being weighted with the natural log of the sum of the two reports.

$$
\left|\ln \left(\frac{V M_{(F O B)}}{V X_{(F O B)}}\right)_{i, j}^{h s 6, t}\right|=\sum_{i} \alpha_{i} \cdot I_{i}+\sum_{j} \beta_{j} \cdot I_{j}+\sum_{t} \gamma_{t} \cdot I_{t}+\sum_{h s 6} \lambda_{h s 6} \cdot I_{h s 6}+\text { error }
$$

$V M$ and $V X$ are respectively the report by the importer (from which the estimated CIF has been removed: see below) and by the exporter (valued FOB). I denote dummy variables for exporters (index $i$ ), importers (index $j$ ) or products (index hs6). Estimated country fixed effects give the marginal impact on discrepancies between reported flows that can be attributed to country characteristics cleaned from sectoral and temporal effects. We assume they represent the (relative) reliability of a country data report, that will be used as weights in the reconciliation of bilateral flows.

\subsection{Handling freight and insurance costs}

Besides reconciling the data, the aim was to have a matrix of world trade free of freight costs. Import values are reported CIF (cost, insurance and freight) and the exports are reported FOB (free on board). We use a gravity-type equation to get the FOB-FOB data. To allow the comparison between mirror declarations, CIF costs have to be estimated and removed from import values to compute FOB import values. This procedure is not applied when it widens the gap between mirror flows. We use a gravity-type equation to estimate them, by OLS on pooled data.

$\ln \left(\frac{U V M_{(C I F)}}{U V X_{(F O B)}}\right)_{i, j}^{h s 6, t}=\beta_{1} \cdot \ln \left(\right.$ dist $\left._{i, j}\right)+\beta_{2} \cdot \ln \left(\text { dist }_{i, j}\right)^{2}+\delta \cdot$ landlocked $_{j}+\gamma \cdot \ln \left(u v^{h s 6, t}\right)+u_{t}+\varepsilon_{i j t}$

\footnotetext{
12

Among better reporters we find most of industrialised countries but also some emerging and developing countries, in particular Latin American as well as East-European countries.

13 For instance, what matters is the share of poor/good reporters in its trade partners and the share of products with frequent report errors, for instance because of lack of homogeneity in the 6-digit position.
} 
The right-hand-side variables are bilateral distance, dummies for adjacent and for landlocked countries, dummies for years, and world median unit-value for each product. We consider a non-linear relationship between CIF-FOB ratios and distance by introducing also the square distance. $U V M$ and $U V X$ are respectively the unit value reported by the importer (valued CIF) and by the exporter (valued FOB). The dependent variable is the unit-value ratios reported for a given elementary flow, rather than the ratios of mirror values, because we observe a strong positive relationship between value and quantity ratios (errors, or non-documented differences in ways of reporting are likely to affect values and quantities in the same way). For the same reason, we also weight observations by the inverse of the gap between reported mirror quantities, noted $Q X$ and $Q M$ : $\operatorname{Min}\left(Q X_{i j}, Q M_{j i}\right) / \operatorname{Max}\left(Q X_{i j}, Q M_{j i}\right)$, where $i$ is the exporter and $j$ is the importer.

Since this gives the higher weight to trade flows equally reported by partners, differences between reported import and export values are then more likely to be freight costs.

\subsection{Allocating varieties shipped to market segments}

Contrary to the literature on Intra-Industry trade broadly equating unit values and quality, the interpretation of differences in unit values between exported varieties of the same product in terms of quality only is questionable.

Firstly, the case that rich countries export high price varieties, independently of their level of quality. Using cross-sectional bilateral data for 60 countries in 1995, Hallak (2006-a) asks whether the correlation of export prices with per capita income, and thus with other factors than quality per se, leads to spurious conclusions. Is it quality, or other factors tightly linked to income, such as production costs, that determine export prices?

Secondly, Hallak and Schott (2005) challenge the strong association of prices to quality, stressing that difference in unit values may reflect, not only the quality of the product, but also exchange rate misalignments or differences in production costs. Instead of assuming a one-to-one relationship between unit value and quality, Hallak and Schott extract the "comparative advantage" component of the difference in unit values by taking into consideration sectoral global balances of the exporting country. A country running a trade surplus and selling at a low unit value is considered as having a comparative advantage, rather than selling low quality products ${ }^{15}$. Our bottom line is that quality and other

\footnotetext{
${ }^{14}$ As expected, we find that CIF costs increase with distance and decrease with unit value. Notice that apart from reporting errors, the left-hand-side variables should be only CIF since the net of freight trade value (which depends on distance) is present both in the numerator and the denominator of the ratio of mirror reports variable. Therefore, the effects of distance and other gravity variables on freight and on trade values are identified separately.

15

"Two countries with the same export prices but different trade balances must have products with different levels of quality. Among countries with identical export prices, the country with the higher trade balance is revealed to possess higher product quality.” (op.cit. p. 2).
} 
characteristics differentiating varieties exported, lead to the observed differences in unit values.

The classification of unit values of exported varieties in three ranges (low, medium, high) which we adopt thinks of a continuum of vertically differentiated products. Indeed, we use data at the 6-digit level, involving different tariff lines aggregated under the same HS6 heading, reported by several firms of a given country on several dates by year. Such trade flows must be heterogeneous. Consequently, instead of classifying each trade flow in a unique vertical specialisation positioning, we propose a smoother procedure that divides each elementary trade flow into two ranges, either low range and medium range, or medium range and high range.

In order to avoid the generally observed threshold effects in the classification of trade flows within quality ranges, we proceed as follows. We define the relative unit value ratio for any trade flow $s$ :

$r=\left(U V_{s} / U V_{\text {world }}\right)$, the reference group is the trade weighted (geometric) average of $U V$ over all flows in the world.

- If $r<1$ then the value of flow $s$ is divided into low and medium ranges as follows: the share of low range is $\left(1-r^{\alpha}\right)$ and the share in medium range is the complement $\left(r^{\alpha}\right)$;

- If $r>1$ then the value of flow $s$ is divided into high and medium ranges as follows: share in top range is $\left(1-1 / r^{\alpha}\right)$ and share in medium range is $\left(1 / r^{\alpha}\right)$;

- If $r=1$ the whole flow is ascribed to medium range.

Using this procedure, there are no more threshold effects: A small change in $\alpha$ implies a small change in quality classification. The lower $\alpha$, the higher the share of trade in the medium range.

However, one shortcoming of this method for allocating trade flows to market segments is that it does not ensure stability of the shares of the three segments for the world total. To overcome this puzzling issue and as a robustness check, we applied a more simple method: market segments are simply defined by percentiles in each year (down-market under the $33^{\text {th }}$ percentile of unit-values, up-market above the $67^{\text {th }}$ percentile, middle-market in the middle of the distribution). Results presented in the Annex stress that our conclusions are robust to such a change.

\footnotetext{
16 The composition of exports may vary with distance, if transport costs are not of an iceberg type but embody a fixed cost. In the latter case the Alchian-Allen conjecture where the quality increases with the fixed cost and hence the distance, known as "the better apples are exported" hypothesis, should play a role in the observed unit values (Hummels and Skiba, 2004). 17

The only departure between both methods, discussed below, is the assessment of the change in the EU market share in the upper segment of the market. With constant market share we observe a resilience, as compared with the US and Japan, if no increase, while the method in the core of the paper points to a slight 
An additional problem is that the matrix of world trade is not completely filled, even when mirror reports are taken into account. In particular, quantities are not systematically reported for certain reporters. For instance, if India does not report the quantity shipped of a given product to a given market and if the importer is not reporting its trade at all, then the quantity will not be available. When the quantity is missing, and calculating bilateral market shares for up-market varieties, we assume that non allocated flows are distributed by market segment in the same way as allocated flows. As concerns world market shares by market segment, dropping non allocated flows would minimise the world market share of countries having more missing quantities. Therefore, we attribute missing flows to market segments in proportion of the allocated flows, for each pair of countries before computing market shares.

\section{LIMITED SIMILARITY AMONG VARIETIES OF PRODUCTS JOINTLY EXPORTED BY NORTH AND SOUTH}

We start by calculating ratios of unit values by pair of countries (importer/exporter) in order to assess to what extent varieties of products jointly exported by the two countries in the pair are dissimilar. We take advantage of the time coverage of our sample to compare the results for 1995 and 2004, and thus to check whether a convergence of specialisation within products between North and South is taking place.

In a second stage, we examine the relationship between the specialisation within products, as defined by the unit value of exported varieties of each product, and the level of development of the exporter. Estimations are made at the product level, in order to take into account the expected differences between products. This is done for three markets, over 10 years and we examine the distribution of the estimated elasticity across products, by market.

\subsection{North and South export different varieties of the same products}

The North and South may indeed export the same bundle of products, in contrast to the standard view of international trade, but they will specialise in different varieties shipped at different unit values. We attempt here to systematise such repeated observation in the literature. A key issue is whether such differences in unit values of varieties exported by the North and the South are only transitory, reflecting delays in market adjustments, or sustainable, reflecting a systematic pattern in the international division of labour.

In order to do this, we rely on our exhaustive set of exporters and importers and ask what the overall evidence is at the world level. We accordingly calculate bilateral unit-value ratios for varieties exported by the North and the South on each destination market at the HS6 level of the nomenclature of traded products.

increase. This does not modify the contrasted picture with Japan and the USA which definitively concede more market shares in the upper segment, whatever the method. 
The ratio of export unit-value for a country pair $(A, B)$ is the weighted median of $U V_{A, j}^{k} / U V_{B, j}^{k} \quad$ where $j$ is the direction of export. The weighting variable is $w=0.5\left(V_{A, j}^{h s 6} / V_{A}+V_{B, j}^{h s 6} / V_{B}\right)$ where $V_{A}$ and $V_{B}$ are the total exports of A and B. These ratios are computed for each year. Intra-EU trade flows are excluded.

To take an example, the question is, how did the relative unit value of "liquid dielectric transformers, having a certain category of power handling capacity”, shipped to the same destination market by the US and by China, vary over the last decade?

Lastly, we aggregate such information, for each pair of countries, in order to examine the evolution of the price gap between pairs of developed and emerging countries.

The result is given in Table 8 for 1995. The median of the distribution of Brazilian prices relative to Chinese prices is 1.46 , meaning that Brazilian prices were 46 percent higher than Chinese ones in 1995. Reciprocally, the median of the distribution of Chinese prices relative to Brazilian prices is .68 $(=1 / 1.46)$, meaning that Chinese prices were two thirds of Brazilian prices in 1995. Generally speaking, Brazil did not exhibit in 1995 prices so different from those in advanced economies (94 percent of US prices, 76 percent of Japanese prices, 71 percent of EU prices). Accordingly, Brazil might well be specialised in certain products, in a traditional way, rather than in varieties within products.

The opposite is observed for China. With prices in 1995 representing 31 percent of Japanese prices, 30 percent of European prices, 42 percent of US prices or even 87 percent of Indian prices, for the same products, China was clearly specialised on the lower segment of the market, for the bulk of its exported varieties in 1995. India was exhibiting the same type of specialisation, however it was less pronounced: 43 percent of European prices, 44 percent of Japanese prices, 64 percent of US prices.

Table 8: Median relative unit values observed at the product level, 1995

\begin{tabular}{lrrrrrrrr}
\hline \hline & Brazil & China & Japan & Russia & India & USA & EU25 & Oth. Em. \\
\hline Brazil &. & 0.68 & 1.32 & 0.92 & 0.88 & 1.06 & 1.40 & 1.00 \\
China & 1.46 &. & 3.25 & 0.98 & 1.15 & 2.36 & 3.39 & 1.31 \\
Japan & 0.76 & 0.31 &. & 0.61 & 0.44 & 0.92 & 1.01 & 0.52 \\
Russia & 1.08 & 1.02 & 1.65 &. & 1.06 & 1.22 & 1.35 & 1.13 \\
India & 1.14 & 0.87 & 2.29 & 0.94 &. & 1.55 & 2.32 & 1.07 \\
USA & 0.94 & 0.42 & 1.08 & 0.82 & 0.64 &. & 1.17 & 0.73 \\
EU25 & 0.71 & 0.30 & 0.99 & 0.74 & 0.43 & 0.85 &. & 0.55 \\
Oth. Em. & 1.00 & 0.76 & 1.92 & 0.89 & 0.93 & 1.38 & 1.82 &. \\
\hline \hline
\end{tabular}

Note: A weighted geometric median of relative unit values of country A (in column) and B (in line) across common HS6 positions and geographical destinations of exports (weights are the simple averages of the shares of the export flow in the total exports of A and B) is calculated here.

Source: BACI, authors' calculation. 
More interestingly, the Chinese market positioning has not dramatically changed within a decade, even if we record a slight increase in its prices (Table 9). Over the period considered, Chinese relative prices have gained 4 percentage points vis-à-vis Japan, 3 percentage points vis-à-vis the EU and 4 percentage points vis-à-vis Brazil. In contrast, Chinese relative prices have lost 1 percentage point vis-à-vis the US, and even 7 percentage points vis-à-vis India. Accordingly, the outcome of a specialisation on varieties within products is a rather stable pattern.

Table 9: Median relative unit values observed at the product level, 2004

\begin{tabular}{lrrrrrrrr}
\hline \hline & Brazil & China & Japan & Russia & India & USA & EU25 & Oth. Em. \\
\hline Brazil &. & 0.81 & 1.43 & 1.00 & 0.96 & 1.16 & 1.48 & 1.04 \\
China & 1.23 &. & 2.86 & 1.17 & 1.25 & 2.44 & 3.06 & 1.43 \\
Japan & 0.70 & 0.35 &. & 0.75 & 0.54 & 1.00 & 1.08 & 0.70 \\
Russia & 1.00 & 0.85 & 1.34 &. & 1.13 & 1.26 & 1.36 & 1.08 \\
India & 1.04 & 0.80 & 1.86 & 0.89 &. & 1.58 & 2.05 & 1.07 \\
USA & 0.86 & 0.41 & 1.00 & 0.79 & 0.63 &. & 1.12 & 0.81 \\
EU25 & 0.68 & 0.33 & 0.92 & 0.73 & 0.49 & 0.90 &. & 0.57 \\
Oth. Em & 0.96 & 0.70 & 1.43 & 0.92 & 0.93 & 1.23 & 1.77 &. \\
\hline \hline
\end{tabular}

Note: A weighted geometric median of relative unit values of country A (in column) and B (in line) across common HS6 positions and destinations of export (weights are the simple averages of the shares of the export flow in the total exports of A and B) is calculated here.

Source: BACI, authors’ calculation.

Beyond the classification of trade flows within market segments, a key issue is whether export prices of varieties of individual products have converged over the last decade. Considering all manufactured products, and focusing on the relationship between the EU and China in the first panel of Figure 3, we cannot conclude that such catching up has occurred. The ratio varies around 3, meaning that on average EU exported varieties are three times more expensive than Chinese varieties of the same products. Were the products are homogenous, such difference in prices should have led within a decade to a profound redistribution of market shares, which has not been observed. European exporters are still in the market, despite their high prices, meaning that products are considerably (vertically) differentiated. There is an exception however, for professional equipment ("investment goods”). In the latter sector, a rapid convergence of prices is observed between China and the EU: the varieties exported by the two countries are increasingly similar. The second panel of Figure 3 plots the prices of US products relative to Chinese products. The differences are less striking than in the European case. The convergence of relative prices of professional equipment is also recorded here.

European and US prices compared to emerging economies - not including China - are plotted in the third and fourth panels, pointing to a divergence of European and US prices for consumer goods. 
Figure 3: North-South relative prices for manufactured, intermediate, consumer, investment and Hi-tech products (1995-2004)

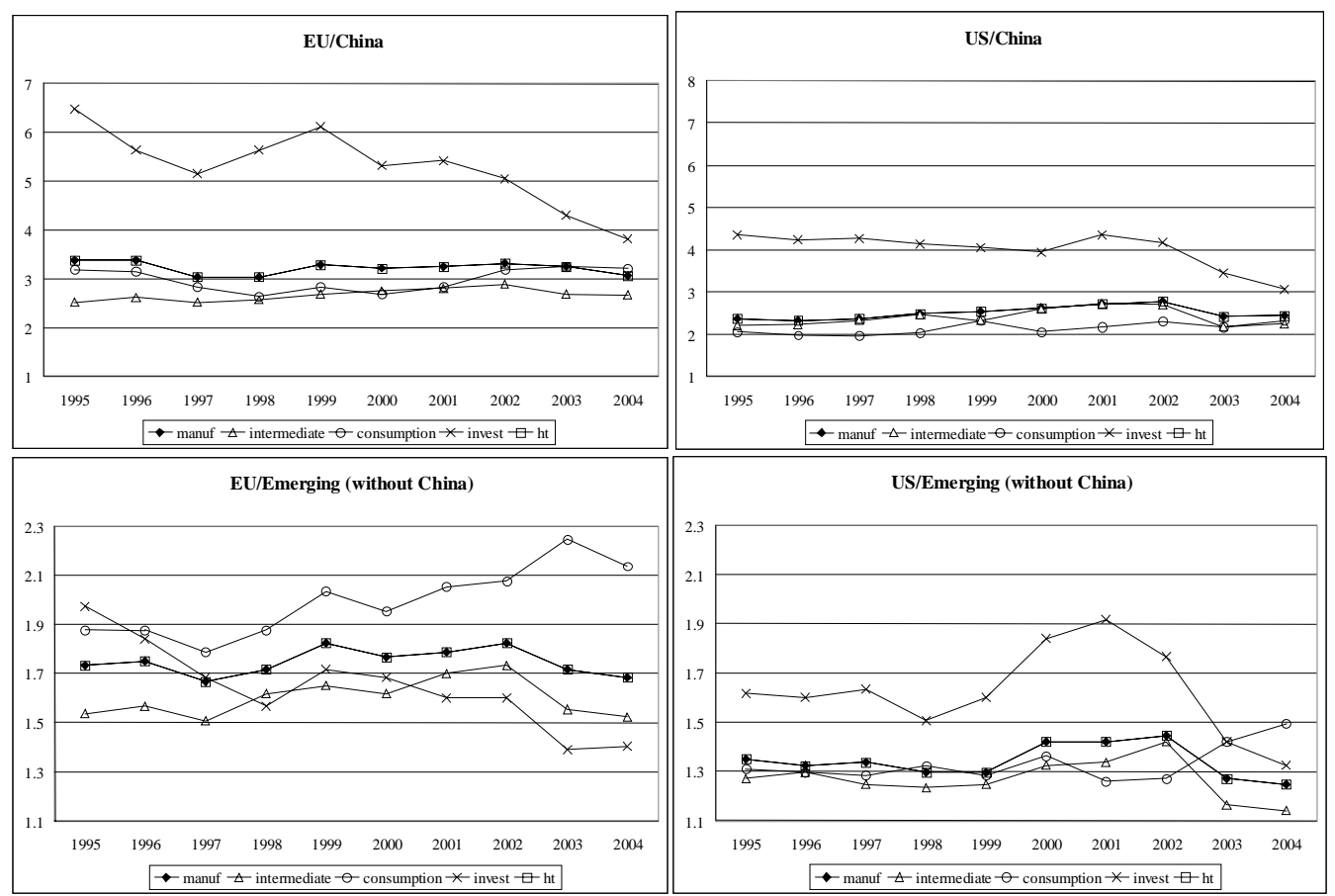

Note: see Table 8.

Source: BACI, authors’ calculation.

\subsection{Determinants of the market positioning of varieties}

How have such differences in relative prices of varieties among exporters been sustainable during a decade without profound swings in market shares among exporters? In order to tentatively answer this question, we will extend the empirical analysis on US imports by Schott (2004), by using a world sample. Schott regresses unit-values of American imports on proxies of exporter's level of development or factor intensities. We will replicate the exercise for three comparable importers and the same disaggregation of the data: USA, EU and Japan. We will estimate an econometric equation explaining the unit value of each individual trade flow (exporter, importer, HS6 product, year) by the per capita GDP of the exporter. This is a very simple methodology. Our value added, beyond extending the exercise to Japan and the EU as importers, is however twofold.

Firstly, in order to better shed light on the actual patterns of North-South competition, we select the products that are sourced simultaneously and significantly in the North and the South. In order to do so, we take the first quartile of the distribution of market shares of OECD and emerging exporters (referred to as North and South respectively) in each developed market (across all products) as thresholds. We will retain only the 6-digit 
products for which the market share of South and North is larger than the respective thresholds. This procedure permits us to focus on the products for which North and South are actually competing in each Triad market.

Secondly, we consider the distribution of the estimated elasticity, by importing country. We have some 5,000 products in total within the HS6 classification, but less when the sample is restricted to manufacturing and even less when it is restricted to products exported by both the North and the South. Lastly, we have a window of ten years corresponding to our panel data. Accordingly, we can estimate the impact of the level of development of exporters for each individual HS6/year/importer, summing to (e.g. for the EU) 21,967 equations giving the same number of estimated elasticities.

The impact of the level of development of the exporter (here, proxied by its Purchasing Power Parity GDP per capita) on the price of the varieties exported, very much depends of the product considered. Whether the product is differentiated or not and the extent to which vertical differentiation is possible, will certainly impact on this relationship. Where varieties are highly differentiated, the upper market segment will correspond to production functions intensive in R\&D, skills and organisation and this is where advanced economies will be advantaged. Lastly, when one considers a large market such as the EU, imports of different varieties of each individual group of products (HS6 heading) will reveal the matching of foreign countries' individual endowments and production function prerequisites. This is why we must rely on estimates made at the product level, rather than within large industries.

Our estimation confirms the findings of Schott (Table 10): the price of varieties imported is positively related to the development level of the exporter. This is true for the three large importing markets. The detailed estimations will now clarify why the parameter differs for the three importers.

Table 10: Impact of the level of development of the exporting country on the unit value of products imported by the EU, Japan and USA (pooled data)

\begin{tabular}{lrrrrrr}
\hline \hline Importer: & $\begin{array}{r}\text { Estimated } \\
\text { parameter }\end{array}$ & standard & $\mathrm{t}$ & $\mathrm{R}^{2}$ & $\mathrm{~N}$ & $\mathrm{~F}$ \\
\hline US & 0.378 & 0.002 & 182.41 & 0.0484 & 653,633 & 33,274 \\
Japan & 0.429 & 0.002 & 191.79 & 0.0796 & 425,242 & 36,782 \\
EU (*) & 0.352 & 0.001 & 501.37 & 0.0635 & $3,710,189$ & 251,377 \\
\hline \hline
\end{tabular}

Note: The following equation is estimated for a sample in which products are sourced simultaneously and significantly in the North and the South: $\ln U V_{i, h s 6, t}=C_{h s 6, t}+\beta \cdot \ln G D P P C_{i, t .}$.

Source: BACI, authors’ calculation. 
While we exclude intra-EU exports in our exercise, trade flows are recorded for member states on an individual basis since there is no simple way of aggregating their unit values otherwise (results would be affected by the aggregation method). We estimate equations by pooling data what leads to many more observations for the European market, more degrees of freedom and a more precise estimation of the elasticity. This gain in precision translates into a higher concentration of parameter estimates.

Instead of relying on overall estimates, we now consider the distribution of such elasticity on the three markets of the Triad. In Appendix 6-1 we plot the distribution of the estimated parameters for the EU. The median elasticity is .35, meaning that a 10 percent increase in the GDP per capita of the exporter to the EU will translate into a 3.5 percent increase in the price of its exported products, for a given product. The lower quartile of the distribution is 0.21 and the upper one 0.54 . This distribution validates our explanation despite the interproduct categories variance of the estimated coefficient. ${ }^{19}$ The same calculation is done for the Japanese and US markets and the respective distributions are plotted in Appendix 6-2 and Appendix 6-3.

These results confirm the remarkable robustness of the underlying relationship: with economic development, as skills, capital intensity, R\&D capacity and organisational capacities increase, countries climb the ladder of vertical differentiation between varieties of exported products.

\section{SUPPLY AND DEMAND DETERMINANTS OF TRADE IN VARIETIES}

In this section, we tentatively explain the market positioning of exporters on the basis of the assumption of a matching between the varieties traded and country characteristics. We address the role of supply and demand related determinants, in the line of the theoretical arguments referred to above. On the supply side, rich countries should be advantaged in exporting up-market products. On the demand side rich countries should purchase and import more up-market products and reciprocally for developing economies.

\footnotetext{
18 However, this potentially raises the issue of heterogeneity among Member states. We accordingly performed the estimation on a (EU) country by country basis. EU member states are quite homogeneous as concerns unit-value elasticity to GDP per capita. The median of estimated coefficients ranges from .22 (Ireland) to .45 (Greece) with even more homogeneity within the group of largest countries: Germany (.35), France (.33), Italy (.41), UK (.29). The median of member states (median) coefficients is .38, which is very close to the figure obtained when all EU countries are pooled together. 19

In Appendix 6.1, EU members states are pooled together so as there is only one coefficient for each combination product, year. Alternatively one can allow coefficients to be Member state-specific. The distribution of the 327,190 parameters obtained (one for each triplet product, year, EU member state) is plotted in the Appendix 6. Results are globally the same, with a median parameter of .40. Details are provided in Appendix 6.
} 


\subsection{A gravity equation accounting for the market positioning of varieties and for the direction of trade}

The basic framework is the workhorse of empirics in international trade, namely an augmented gravity equation.

The dependent variable is the value of bilateral exports from country $i$ to country $j$ at year $t$ into market segment $g$. We estimate it once for total exports and then at the sectoral level, where sector characteristics are controlled for using sector fixed effects. Among the three market segments, only two are considered: up market and down market.

The GDPs of exporter and importer are of course introduced, as well as distance. GDP data are taken from the World Development Indicators (2006). It should be noticed that we use a harmonic average of CEPII distances, taking into account internal distances. This distance measure is using city-level data to assess the geographic distribution of population (in 2004) inside each nation. The idea is to calculate distance between two countries, based on bilateral distances between the biggest cities of those two countries, those inter-city distances being weighted by the share of the city in the overall country's population. This procedure can be used in a totally consistent way for both domestic and international distances. The distance is based on data of the World Gazetteer web site, which provides current population figures and geographic coordinates for cities, towns and places of all countries. The calculation is based on the general formula developed by Head and Mayer (2002), where pop $_{k}$ designates the population of agglomeration $k$ belonging to country $i$. Sigma measures the sensitivity of trade flows to bilateral distance $d_{k l}$ and is set to -1 , which corresponds to the usual coefficient estimated from gravity models of bilateral trade flows:

$$
d_{i j}=\left(\sum_{k \in i}\left(\operatorname{pop}_{k} / \text { pop }_{i}\right) \sum_{l \in j}\left(\operatorname{pop}_{l} / \operatorname{pop}_{j}\right) d_{k l}^{\sigma}\right)^{1 / \sigma}
$$

This variable taking into account internal distances makes it unnecessary to introduce a control for contiguity. Bilateral distance may have two different impacts. Firstly, as a proxy for transport costs, distance increases the relative price of the lower-market segment for the consumer, in the same way as a specific tariff. This should increase the share of the uppermarket segment in imports. Secondly, distance is a proxy for lack of information on products and may reduce the consumption of expensive products. Which of these is the dominant effect is a matter of empirics.

Since cultural proximity may play an important role in the demand for up-market products differentiated by brands or other intangible attributes, we introduce a dummy for common language. Bilateral distances and common language are from the CEPII geographical database.

${ }^{20}$ This data is available at: http://www.cepii.fr/anglaisgraph/bdd/distances.htm. 
More importantly, the GDP per capita of the exporter (supply side determinant) as well as for the importer (resp. demand side) are introduced. PPP GDPs per capita data are from the World Development Indicators (2006).

Lastly, border protection is taken into account through tariffs (defined at the product level). Tariffs may affect varieties within the low and high market segments in different ways. This is obvious for a specific tariff. But this is true also for an ad valorem tariff, of the type considered here. If the mark-up is very large in the upper-market segment, the exporters may be prepared to reduce their price at the frontier in order to keep access to the market. This pass through of costs, similar to the behaviour observed in the case of exchange rates changes, should lead to a lesser sensitivity of the upper segment to tariffs. Tariffs used are from the CEPII Trade and Production database, which extends the World Bank's Trade and Production 1976-1999 database, by adding bilateral data on trade policy by industrial ISIC sector. ${ }^{21}$ Tariffs are aggregated from TRAINS, as compiled by Jon Haveman, in order to match the ISIC rev2 industry classification using the world imports as weights for HS6 products. We also add dummies in the regressions, aimed at identifying different combinations of flows between the North and the South. The reference dummy in the regressions is the one concerning North-North flows.

Concerning the interaction variables, we consider the market segment each elementary bilateral trade flow belongs to: either the lower or the upper market segment. The corresponding dummy variables ( $g_{1}$ and $g_{3}$ respectively) are interacted with distance (does one ship the good apples?), with common language (is the upper segment of the market more sensitive to cultural proximity?), with GDP per capita (what is the role of supply and demand related determinants?) and tariffs. Accordingly, we expect a negative coefficient on dummies pertaining to South flows when the upper segment is concerned, a positive coefficient in the case of low market segment. In addition, we interact $g_{1}$ and $g_{3}$ with the direction of the bilateral trade relationship: exporter in the North, importer in the North $(N N)$, exporter in the South, importer in the North $(S N)$, and so on for SS and NS. In the estimations, $N N$ is taken as the benchmark case.

For the second estimation, we use sectors as classified by the ISIC, in which there are 25 manufactured sectors. In each sector, the classification of exports in each market segment is made at the product level before summing the values attributed to each segment in each sector.

${ }^{21}$ This data is available at: http://www.cepii.fr/anglaisgraph/bdd/TradeProd.htm. 22

We classify countries into two large groups: developed economies (“North”), and developing economies ("South"). We here use the World Bank countries classification by income to define the North and the South. 
We proceed with weighted OLS estimates. Observations (bilateral trade flows) are weighted by the log of their value. Working with a very large and heterogeneous data set, we avoid giving the same importance to tiny trade flows, more likely to be measured erroneously and very large trade flows between major countries.

The standard gravity equation includes prices or country fixed effects aimed at controlling for prices. We however do not include country fixed effects (for exporters and importers) because of collinearity with bilateral relationship variables. When both (unilateral) country fixed and bilateral relationship variables are introduced their respective impact cannot be estimated independently. The bilateral relationship variables are preferred here as they provide more relevant information about North-South trade patterns. Besides, the estimates of elasticities to GDP and GDP per capita, which are of interest to us, are affected when a set of country dummies is introduced (evidence of quasi multicolinearity).

All variables are in logarithm. We introduce time fixed effects in order to control for annual changes in the value of world trade (the period is 1995-2004) and sectoral (ISIC) fixed effects. In total the estimated equation at the sectoral (ISIC) level is:

$$
\begin{aligned}
\ln X_{i j, k}^{t}= & \alpha+\beta_{1} \ln G D P_{i}^{t}+\beta_{2} \ln G D P_{j}^{t}+\beta_{3} g_{1} \ln G D P P C_{i}^{t}+\beta_{4} g_{3} \ln G D P P C_{i}^{t}+\beta_{5} g_{1} \ln G D P P C_{j}^{t} \\
& +\beta_{6} g_{3} \ln G D P P C_{j}^{t}+\delta g_{1} Z_{i j}^{t}+\chi g_{3} Z_{i j}^{t}+\phi g_{1} D I R_{i j}^{t}+\eta g_{3} D I R_{i j}^{t}+u_{k}+v^{t}+\varepsilon_{i j, k}^{t}
\end{aligned}
$$

where $Z$ is a vector of bilateral resistance terms (distance, culture, tariffs), $D I R$ is a vector of dummies indicating the direction of bilateral trade (North-North, South-North, etc.) and $k$ indicates the industry $(k=1, \ldots 25)$. The two first columns in Table 11 are dedicated to the equation estimated on total trade flows. The last two columns give the results of the estimations done with the panel of sectors. We report in column (1) results for the largest sample (273,046 observations), which does not include tariff data. When tariffs are introduced, we loose a lot of observations in column (2). ${ }^{23}$ Columns (3) and (4) report the results for the estimations at the sectoral level (ISIC sectors), respectively without and with tariffs. The number of observations peaks at 2.802 million when tariffs are excluded, which is less than 25 times 273,046 since not all countries export to a given market in a given industry.

\subsection{Supply and demand determinants of trade in varieties validated}

The GDP and distances variables have the expected sign and order of magnitude. More interestingly, we can now assess the theoretical predictions referred to above. The parameters on distance interacted with the market segment of the exported varieties (low versus high) illustrate the Alchian-Allen hypothesis. Low price varieties are more sensitive

23 Our tariffs database reports many years in the nineties but stops in 2000 and covers "only" 118 reporting countries.

24

Estimations excluding year fixed effects are provided in Appendix 4, for sake of comparison. 
Table 11: Explaining bilateral exports in a panel of 163 countries and 10 years

\begin{tabular}{|c|c|c|c|c|}
\hline & $\begin{array}{c}(1) \\
\text { Total trade } \\
\text { Without tariffs }\end{array}$ & $\begin{array}{c}(2) \\
\text { Total trade } \\
\text { With tariffs }\end{array}$ & $\begin{array}{c}\text { (3) } \\
\text { Sectoral trade } \\
\text { Without tariffs }\end{array}$ & $\begin{array}{c}(4) \\
\text { Sectoral trade } \\
\text { With tariffs }\end{array}$ \\
\hline \multirow[t]{2}{*}{ Intercept } & -28.49 & -30.80 & -22.45 & -25.40 \\
\hline & $(0.12)$ & $(0.33)$ & $(0.05)$ & $(0.11)$ \\
\hline \multirow[t]{2}{*}{ Low prices } & 1.30 & 1.97 & 1.83 & 2.34 \\
\hline & $(0.15)$ & $(0.41)$ & $(0.06)$ & $(0.14)$ \\
\hline High prices & Ref. & Ref. & Ref. & Ref. \\
\hline \multirow[t]{2}{*}{ Distance * low } & -1.11 & -1.12 & -0.80 & -0.75 \\
\hline & $(0.01)$ & $(0.01)$ & $(0.00)$ & $(0.00)$ \\
\hline \multirow[t]{2}{*}{ Distance * high } & -1.04 & -1.10 & -0.74 & -0.68 \\
\hline & $(0.01)$ & $(0.01)$ & $(0.00)$ & $(0.00)$ \\
\hline \multirow{2}{*}{ Common language $*$ low } & 0.82 & 0.80 & 0.57 & 0.61 \\
\hline & $(0.01)$ & $(0.03)$ & $(0.00)$ & $(0.01)$ \\
\hline \multirow[t]{2}{*}{ Common language * high } & 0.98 & 0.89 & 0.66 & 0.67 \\
\hline & $(0.01)$ & $(0.03)$ & $(0.00)$ & $(0.01)$ \\
\hline \multirow[t]{2}{*}{ Exporter GDP } & 0.95 & 1.01 & 0.71 & 0.77 \\
\hline & $(0.00)$ & $(0.00)$ & $(0.00)$ & $(0.00)$ \\
\hline \multirow[t]{2}{*}{ Importer GDP } & 0.74 & 0.75 & 0.58 & 0.60 \\
\hline & $(0.00)$ & $(0.00)$ & $(0.00)$ & $(0.00)$ \\
\hline \multirow[t]{2}{*}{ Exporter GDP per cap. * low } & 0.31 & 0.40 & 0.02 & 0.01 \\
\hline & $(0.01)$ & $(0.02)$ & $(0.00)$ & $(0.01)$ \\
\hline \multirow[t]{2}{*}{ Exporter GDP per cap. * high } & 0.33 & 0.43 & 0.07 & 0.08 \\
\hline & $(0.01)$ & $(0.02)$ & $(0.00)$ & $(0.01)$ \\
\hline \multirow[t]{2}{*}{ Importer GDP per cap. * low } & 0.05 & 0.04 & 0.01 & -0.01 \\
\hline & $(0.01)$ & $(0.02)$ & $(0.00)$ & $(0.01)$ \\
\hline \multirow{2}{*}{ Importer GDP per cap. * high } & 0.13 & 0.16 & 0.15 & 0.15 \\
\hline & $(0.01)$ & $(0.02)$ & $(0.00)$ & $(0.01)$ \\
\hline \multirow[t]{2}{*}{ Tariffs * low } & 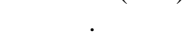 & -1.05 & . & -1.46 \\
\hline & . & $(0.21)$ & . & $(0.05)$ \\
\hline \multirow[t]{2}{*}{ Tariffs * high } & . & -1.24 & . & -0.77 \\
\hline & . & $(0.22)$ & . & $(0.05)$ \\
\hline \multirow[t]{2}{*}{ SS * low } & 0.49 & 0.70 & 0.50 & 0.69 \\
\hline & $(0.02)$ & $(0.06)$ & $(0.01)$ & $(0.02)$ \\
\hline \multirow[t]{2}{*}{ SS * high } & -0.70 & -0.51 & -0.67 & -0.51 \\
\hline & (0.03) & $(0.06)$ & $(0.01)$ & $(0.02)$ \\
\hline \multirow[t]{2}{*}{$\mathrm{SN} *$ low } & 0.26 & 0.47 & 0.20 & 0.26 \\
\hline & $(0.02)$ & $(0.06)$ & $(0.01)$ & $(0.01)$ \\
\hline \multirow[t]{2}{*}{ SN * high } & -0.61 & -0.48 & -0.85 & -0.78 \\
\hline & $(0.02)$ & (0.06) & $(0.01)$ & $(0.02)$ \\
\hline \multirow{2}{*}{ NS * low } & -0.13 & 0.11 & -0.05 & 0.25 \\
\hline & $(0.02)$ & (0.06) & $(0.01)$ & $(0.02)$ \\
\hline \multirow[t]{2}{*}{ NS * high } & -0.54 & -0.30 & -0.48 & -0.23 \\
\hline & $(0.02)$ & $(0.06)$ & $(0.01)$ & $(0.02)$ \\
\hline $\mathrm{NN}$ & Ref. & Ref. & Ref. & Ref. \\
\hline $\mathrm{R} 2$ & 0.673 & 0.719 & 0.463 & 0.476 \\
\hline Fisher & $21,641.1$ & $4,483.3$ & 47,333.6 & $11,883.4$ \\
\hline$P$ value & $<.0001$ & $<.0001$ & $<.0001$ & $<.0001$ \\
\hline $\mathrm{N}$ & 273,046 & 42,079 & $2,802,011$ & 641,717 \\
\hline
\end{tabular}

Source: BACI-CEPII. Authors' calculations. 
to transaction costs than high price ones. This result holds in all specifications here. Regarding tariffs, which are added on top of freight costs, it is however difficult to conclude. At the global level, the elasticity is larger, in absolute terms, for high-price varieties. This result reverses when the sectoral dimension of the data is controlled for. A plausible explanation is that tariffs are higher in sectors where varieties exported by the South are sold at low prices.

The second series of theoretical predictions concerns the supply and demand effects of the level of development on the unit value of shipped varieties. How bilateral trade flows are modelled here leads to a peculiar interpretation of the two variables of income per capita interacted with the market segment of the varieties. Since we control for the direction of trade flows in the equation (South-North for instance), what we capture here is both the relative position of every exporter (importer) in its respective group and the increase in its level of development over time. Do we observe a within product specialisation in line with standard trade theory? The answer is yes. Having controlled for the direction of trade flows, we check that the elasticity associated with the interacted variable on the per capita GDP of the exporter is larger for up-market varieties. When tariffs are taken into account, the difference between the two elasticities is limited at the global level (.402 versus .431); But it becomes very large when the sectoral dimension of the data is taken into account $(.007$ versus .076).

Turning to the demand side effects, we ask whether countries import more of those varieties shipped at a higher unit value, when their income increases. We observe a large difference in the parameter estimated on the importer GDP per capita variable, when it is interacted with $g_{3}$ instead of $g_{1}$, illustrating that marginal income may be spent on quality rather than on quantity. When the sectoral dimension and the tariffs are taken into account, we even capture a negative impact of an increase in per capita income on imports of low price varieties.

Lastly, what is the direction of trade in varieties of the same products shipped at different unit values? We use the direction North-North as the benchmark (parameter is set to 0 ).

Bilateral trade in up-market varieties is particularly intense when exporter and importer are developed (high purchasing power and overlap of income distributions). Then comes the North shipping varieties to the South $(-0.541$ in column 1), then the South shipping varieties to the North (resp. -0.613), followed by the South to the South (resp. -0.700). The same result holds for total trade in column 2 when tariffs are introduced.

Conversely, bilateral trade in varieties belonging to the low segment of the market is particularly intense when exporter and importer are in the South (0.487 in column 1: limited purchasing power and overlap of income distributions). Exports from the South to the North (0.258) are the next most intense. For the low price segment however, the respective ranking of North to South, and South to North, is dependent on the introduction of tariffs. 
When the unobserved industry characteristics are controlled for in columns 3 and 4, bilateral exports of high price products are the most important among developed countries and the least important from the South to the North. Conversely, exports of low price products are the most important in South-South trade, followed by exports from the South to the North. The respective ranking of South-North and North-South is dependent on the introduction of tariffs.

\subsection{Robustness analysis}

The previously estimated equations did not introduce country effects. However, there is ample evidence and literature that such effects should be introduced in order to control for unobservable prices. Another issue is the specific nature of our sample that includes a series of developing economies. We now address this issue in detail in order to assess the robustness of our previous conclusions. In Table 12, we estimate the same equation as in Table 11, and tentatively introduce fixed effects. We proceed as follows, with total bilateral trade.

In column (5) we estimate the equation of column (1) of Table 11, without weighting the observations. The comparison of these two columns point to the robustness of results to such change. The only difference between the two methods appears for the interacted variable "Exporter GDP per cap. * high", which is not central to our reasoning. The ranking of the variables interacting the direction of trade with the market positioning of varieties is not affected.

In columns (6) to (9) we replicate column (5), but we introduce country fixed effects. The direction of trade is now estimated separately into four equations, for sake of estimation constraints. In column (6) we examine for South-South trade the trade patterns in terms of the market positioning of varieties. Clearly South-South trade is dominated by the low market segment. In column (7) we proceed with South-North flows and reach the same conclusion. In column (9) North-North flows are dominated by the upper market segment. For North South trade however, the interacted variable on low-price is no longer significant.

\section{CONCLUSION}

Availing of a newly available database of bilateral trade, we have systematised in this paper a repeated finding of the trade literature: that there is considerable variation in unit values of traded products at the most detailed level of products classification. Accordingly, international specialisation is taking place within products, across varieties, rather than across products or industries, especially for trade between advanced and emerging economies. Our results point to four stylised facts. 
Table 12: Explaining bilateral exports in a panel of 163 countries and 10 years, with country fixed effects

\begin{tabular}{|c|c|c|c|c|c|}
\hline & $\begin{array}{c}\text { (5) } \\
\text { Total trade } \\
\text { Without tariffs }\end{array}$ & $\begin{array}{c}\text { Total trade } \\
\text { Tithout tariffs } \\
\text { Country fix ef. } \\
\text { Courita }\end{array}$ & $\begin{array}{c}\text { (7) } \\
\text { Total trade } \\
\text { Without tariffs } \\
\text { Country fix ef. }\end{array}$ & $\begin{array}{c}\text { (8) } \\
\text { Total trade } \\
\text { Without tariffs } \\
\text { Country fix ef. }\end{array}$ & $\begin{array}{c}\text { (9) } \\
\text { Total trade } \\
\text { Without tariffs } \\
\text { Country fix ef. } \\
\end{array}$ \\
\hline \multirow[t]{2}{*}{ intcpt } & -32.61 & 5.21 & 4.28 & 4.71 & 4.43 \\
\hline & $(0.14)$ & $(0.88)$ & $(0.88)$ & $(0.87)$ & $(0.88)$ \\
\hline \multirow[t]{2}{*}{ Low Prices } & 0.97 & 2.19 & 4.76 & 4.12 & 4.49 \\
\hline & $(0.17)$ & $(0.13)$ & $(0.11)$ & $(0.11)$ & $(0.11)$ \\
\hline High Prices & Ref. & Ref. & Ref. & Ref. & Ref. \\
\hline \multirow[t]{2}{*}{ Dist * Low } & -1.33 & -1.69 & -1.70 & -1.69 & -1.70 \\
\hline & $(0.01)$ & $(0.01)$ & $(0.01)$ & $(0.01)$ & $(0.01)$ \\
\hline \multirow[t]{2}{*}{ Dist $*$ High } & -1.26 & -1.63 & -1.62 & -1.62 & -1.62 \\
\hline & $(0.01)$ & $(0.01)$ & $(0.01)$ & $(0.01)$ & $(0.01)$ \\
\hline \multirow{2}{*}{ Lang * Low } & 0.97 & 0.80 & 0.79 & 0.79 & 0.79 \\
\hline & $(0.02)$ & $(0.02)$ & $(0.02)$ & $(0.02)$ & $(0.02)$ \\
\hline \multirow[t]{2}{*}{ Lang * High } & 1.19 & 1.04 & 1.05 & 1.04 & 1.04 \\
\hline & $(0.02)$ & $(0.02)$ & $(0.02)$ & $(0.02)$ & $(0.02)$ \\
\hline \multirow[t]{2}{*}{ Exporter GDP } & 1.07 & -0.06 & -0.06 & -0.06 & -0.06 \\
\hline & $(0.00)$ & $(0.02)$ & $(0.02)$ & $(0.02)$ & $(0.02)$ \\
\hline \multirow[t]{2}{*}{ Importer GDP } & 0.78 & 0.23 & 0.23 & 0.23 & 0.23 \\
\hline & $(0.00)$ & $(0.02)$ & $(0.02)$ & $(0.02)$ & $(0.02)$ \\
\hline \multirow[t]{2}{*}{ Exporter GDP per cap. * low } & 0.45 & 0.67 & 0.59 & 0.68 & 0.62 \\
\hline & $(0.01)$ & $(0.05)$ & $(0.05)$ & $(0.05)$ & $(0.05)$ \\
\hline \multirow[t]{2}{*}{ Exporter GDP per cap. * high } & 0.41 & 0.73 & 0.81 & 0.73 & 0.79 \\
\hline & $(0.01)$ & $(0.05)$ & $(0.05)$ & $(0.05)$ & $(0.05)$ \\
\hline \multirow[t]{2}{*}{ Importer GDP per cap. * low } & 0.02 & 0.66 & 0.61 & 0.57 & 0.61 \\
\hline & $(0.01)$ & $(0.05)$ & $(0.05)$ & $(0.05)$ & $(0.05)$ \\
\hline \multirow[t]{2}{*}{ Importer GDP per cap. * high } & 0.11 & 0.73 & 0.77 & 0.82 & 0.78 \\
\hline & $(0.01)$ & $(0.05)$ & $(0.05)$ & $(0.05)$ & $(0.05)$ \\
\hline \multirow[t]{2}{*}{ SS * Low } & 0.34 & 0.67 & & & \\
\hline & $(0.03)$ & $(0.02)$ & & & \\
\hline \multirow[t]{2}{*}{ SS * High } & -0.85 & 0.03 & & & \\
\hline & $(0.03)$ & $(0.02)$ & & & \\
\hline \multirow[t]{2}{*}{$\mathrm{SN} *$ Low } & 0.24 & & -0.45 & & \\
\hline & $(0.03)$ & & $(0.02)$ & & \\
\hline \multirow[t]{2}{*}{$\mathrm{SN} *$ High } & -0.56 & & -0.25 & & \\
\hline & $(0.03)$ & & $(0.02)$ & & \\
\hline \multirow[t]{2}{*}{ NS * Low } & -0.24 & & & -0.66 & \\
\hline & (0.03) & & & $(0.02)$ & \\
\hline \multirow[t]{2}{*}{ NS * High } & -0.59 & & & -0.03 & \\
\hline & $(0.03)$ & & & $(0.02)$ & \\
\hline \multirow[t]{2}{*}{ NN * Low } & & & & & 0.09 \\
\hline & & & & & (0.03) \\
\hline \multirow[t]{2}{*}{ NN * High } & & & & & 0.61 \\
\hline & & & & & $(0.03)$ \\
\hline $\mathrm{N}$ & 281893 & 281893 & 281893 & 281893 & 281893 \\
\hline $\mathrm{R} 2$ & 0.634 & 0.582 & 0.580 & 0.581 & 0.580 \\
\hline
\end{tabular}

Firstly, the similarity of exports between North and South is much more limited when we consider differentiated varieties. When industries are considered, the similarity between Chinese and EU exports is large. When we consider products this similarity is divided by two. When we consider the market positioning of varieties, this similarity is once again reduced. 
Secondly, and this generalises Schott's findings, the unit value of exported products to a certain market varies with the level of development of the exporter. This sheds light on plausible determinants on the supply side.

Thirdly, and according to the role played by traditional determinants of specialisation now operating across varieties, the observed redistribution of market shares at the world level has been especially detrimental to advanced economies for low price varieties, while the EU has better resisted competition in high price varieties, in particular in consumer goods.

Fourthly, bilateral trade in varieties can be explained by a gravity equation controlling for the supply side and demand side determinants considered in the literature, as well as for the direction of trade flows among developing and developed economies.

On the basis of such detailed and systematic empirical evidence regarding the specialisation of countries within - rather than between - products, the fears raised by North-South competition may be exaggerated. China may be exporting under quite as much product headings as Germany, but at the most detailed level of the international classification of products, varieties exported by Germany and China are not in direct competition. And if workers in the North and the South hardly compete on the same varieties, the link between trade and factor prices is somehow weakened (subject to the degree of substitution between high and low quality goods).

Our analysis confirms that advanced economies are keeping an advantage, or are suffering a lesser disadvantage, in the upper market segment. The bottom line of this reasoning is that North and South are not competing head on within industries; However such a conclusion should not hide the plausible domestic impacts of a systematic repositioning on up market varieties by advanced economies. 


\section{REFERENCES}

Choi Y.C., Hummels D. and Xiang C. (2006), Explaining Import Variety and Quality: The Role of the Income Dist $r$ ibut ion, Purdue University, mimeo.

Diaz Mora C. (2002), Role of Comparative Advantage in Trade within Industries: A Panel Data Approach for the European Union, Weltwirtschaftliches Archiv, 138(2): 291316

Falvey, R. E. and H. Kierzkowski (1987), Product Quality, Intra-industry Trade and (Im)perfect Competition, in H. Kierzkowski (ed.), Protection and Competition in International Trade, Basil Blackwell, Oxford \& New York, 143-161.

Feenstra R. C. and G. H. Hanson (1999), The Impact of Outsourcing and High-Technology Capital on Wages: Estimates for the U.S., 1979-1990, Quarterly Journal of Economics, 114(3) : 907-940.

Finger, J.M. (1975), Trade Overlap and Intra-Industry Trade, Economic Inquiry, 13: 581589.

Flam H., Helpman E. (1987), Vertical product Differentiation and North-South Trade, American Economic Review, 77(5): 810-822.

Fontagné L., Freudenberg M. and N. Péridy (1998), Intra-Industry Trade and the Single market: Quality Matters, CEPR Discussion Paper, 1959.

Fontagné L., Freudenberg M., Gaulier G. (2006), A Systematic Decomposition of World Trade into Horizontal and Vertical IIT, Review of World Economics, 142(3): 459-475

Greenaway D., R. Hine and C. Milner (1995), Vertical and Horizontal Intra-industry Trade: A Cross Industry Analysis for the United Kingdom, The Economic Journal, 105(433): $1505-18$

Hallak J.C. (2006-a), Product Quality and the Direction of Trade, Journal of International Economics, 68 (1) : 238-265.

Hallak J.C. (2006-b), A Product-Quality View of The Linder Hypothesis, University of Michigan, mimeo.

Hallak J.C., Schott P.K. (2005), Estimating Cross-Country Differences in Product Quality, Yale University, mimeo.

Head K. and T. Mayer (2002), "Illusory Border Effects: Distance Mismeasurement Inflates Estimates of Home Bias in Trade”, CEPII Working Paper 01. 
Helpman E., Krugman P. (1985), Market Structure and Foreign Trade, Cambridge, MIT Press.

Hummels D., Ishii J. and K.-M. Yi (2001), The Nature and Growth of Vertical Specialization in World Trade, Journal of International Economics, 54 : 75-96.

Hummels D., Klenow P. (2005), The Variety and Quality of a Nations Exports, American Economic Review, 95, 704-723.

Hummels D., Skiba A. (2004), Shipping the Good Apples Out: An Empirical Confirmation of the Alchian-Allen Conjecture, Journal of Political Economy, 112:1384-1402.

International Monetary Fund (2006), Czech Republic, Republic of Estonia, Hungary, Republic of Latvia, Republic of Lithuania, Republic of Poland, Slovak Republic, and Republic of Slovenia-Export Structure and Credit Growth, IMF Country Report No. $06 / 414$.

Linder S.B. (1961), An Essay on Trade and Transformation, New York, John Wiley.

Motta M., Thisse J.-F., and A. Cabrales (1997), On the persistence of Leadership or Leapfrogging in International Trade, International Economic Review, 38(4):809-824.

Naghavi A., Ottaviano G. (2006), Outsourcing, Complementary Innovations and Growth. CEPR Discussion, 5925

Schott P. K. (2004), Across-Product versus Within-Product Specialization in International Trade, Quarterly Journal of Economics, 119(2) : 647-678.

Schott P. K. (2006), The Relative Sophistication of Chinese Exports, NBER working paper 12173.

Torstensson, J. (1991), Quality Differences and Factor Proportions in International Trade: An Empirical Test of the Swedish Case, Weltwirtschaftliches Archiv, 127: 183-194.

Trefler D. (1993), International Factor Price Differences : Leontief was Right!, Journal of Political Economy, 101(1) : 138-160.

Wood A. (1998), Globalisation and the Rise in Labour Market Inequalities, The Economic Journal, (108) :450 1463. 


\section{ANNEXES}

\section{Appendix 1: Results with constant shares for market segments}

Tables 1 and 2 (Similarity of export structures at the sector level, within ISIC categories, and similarity of export structures at the product level are not affected), by the change of methodology. We provide below the affected Tables, using the numeration of the core of the text, preceded by “A” by stake of clarity.

Table A3: Similarity of export structures at the variety level (2004) Method with constant shares of quality ranges

\begin{tabular}{lrrrrrrrr}
\hline \hline & Brazil & China & Japan & Russia & India & USA & EU25 Oth. Em. \\
\hline Brazil & $\cdot$ & & & & & & & \\
China & 0.15 &. & & & & & & \\
Japan & 0.18 & 0.16 &. & & & & & \\
Russia & 0.22 & 0.11 & 0.13 &. & & & & \\
India & 0.20 & 0.21 & 0.13 & 0.15 &. & & & \\
USA & 0.22 & 0.21 & 0.37 & 0.17 & 0.18 &. & 0.24 & \\
EU25 & 0.16 & 0.13 & 0.21 & 0.13 & 0.15 & 0.26 & 0.11 \\
Oth. Em. & 0.13 & 0.13 & 0.1 & 0.1 & 0.13 & 0.12 & 0.12 & 0.11 \\
\hline \hline
\end{tabular}

Note: Similarity between country A (column) and B (row) is the sum of absolute value of differences between the sectoral (ISIC) shares in manufacturing export of country A and those of country B. It lies between 0 (perfect dissimilarity) and 1 (perfect similarity).

Source: BACI-CEPII. Authors' calculations

Table A4: Share of up-market products calculated by constant shares of market segments method, by destination market (2004)

\begin{tabular}{lrrrrrrrrrrr} 
Importer & EU 25 & USA & Japan & Oth. dev & China & Brazil Russia & India & $\begin{array}{r}\text { Oth. } \\
\text { Emerg. }\end{array}$ & RoW & Total \\
\hline Exporter & & & & & & & & & & \\
\hline EU 25 &. & 55.0 & 71.1 & 50.7 & 46.4 & 31.0 & 20.3 & 49.4 & 36.4 & 38.9 & 46.1 \\
USA & 50.5 &. & 61.0 & 31.9 & 42.3 & 26.5 & 22.6 & 49.5 & 14.2 & 31.6 & 35.4 \\
Japan & 52.9 & 29.8 &. & 41.3 & 36.6 & 30.3 & 5.1 & 51.0 & 28.5 & 19.5 & 37.2 \\
Oth. dev & 46.0 & 20.7 & 40.0 & 31.4 & 28.8 & 20.5 & 14.5 & 36.3 & 21.2 & 27.8 & 30.4 \\
China & 14.2 & 2.6 & 12.1 & 5.6 &. & 20.7 & 4.2 & 21.6 & 9.8 & 8.1 & 8.8 \\
Brazil & 29.1 & 16.8 & 44.4 & 16.3 & 8.9 &. & 1.5 & 18.2 & 14.2 & 19.8 & 19.6 \\
Russia & 20.2 & 27.2 & 48.2 & 24.2 & 9.3 & 40.6 &. & 56.1 & 15.7 & 17.9 & 21.7 \\
India & 23.5 & 13.8 & 45.4 & 23.3 & 32.8 & 15.8 & 9.7 &. & 23.2 & 21.2 & 21.8 \\
Oth.Emerg. & 38.4 & 17.2 & 32.6 & 24.2 & 20.9 & 37.1 & 14.4 & 26.8 & 23.0 & 23.0 & 25.5 \\
RoW & 35.1 & 16.3 & 31.9 & 18.7 & 9.0 & 39.3 & 12.2 & 23.0 & 20.2 & 23.6 & 25.0 \\
\hline Total & 38.9 & 26.9 & 40.2 & 32.5 & 33.5 & 29.1 & 16.5 & 37.4 & 23.0 & 29.9 & 31.3 \\
\hline \hline
\end{tabular}

Note: The sample covers manufacturing HS6 goods including food industry. The parameter $\alpha$ that regulates the smoothness of the market segment allocation function (see sub-section 4.5 below) is put to 4 to have around the same value in average in each range for total trade in all products.

Source: BACI-CEPII, authors’ calculation. 
Table A5: World market shares by transformation level and market segment of manufactured products (intra-EU excluded, 2004, percent). Method with constant shares of quality ranges

\begin{tabular}{|c|c|c|c|c|c|}
\hline Market segment & Exporter & Intermediate goods & "Consumer goods & Investment goods & All \\
\hline \multirow{9}{*}{ Lower } & EU 25 & 13.27 & 13.52 & 17.30 & 14.26 \\
\hline & USA & 12.77 & 6.64 & 12.17 & 11.17 \\
\hline & Japan & 7.65 & 4.69 & 8.75 & 7.20 \\
\hline & Oth. devpd & 17.94 & 15.99 & 17 & 17.26 \\
\hline & China & 15.52 & 25.77 & 27.56 & 20.75 \\
\hline & BRI & 7.83 & 6.51 & 2.49 & 6.28 \\
\hline & Oth. Emerg. & 15.83 & 17.81 & 11.2 & 15.23 \\
\hline & RoW & 9.2 & 9.07 & 3.52 & 7.86 \\
\hline & All & 100.0 & 100.0 & 100.0 & 100 \\
\hline \multirow{9}{*}{ Upper } & EU 25 & 28.38 & 39.92 & 28.70 & 31.39 \\
\hline & USA & 14.73 & 9.16 & 19.5 & 14.38 \\
\hline & Japan & 14.32 & 9.04 & 15.35 & 13.2 \\
\hline & Oth. devpd & 22.31 & 13.02 & 19.86 & 19.39 \\
\hline & China & 2.05 & 4.6 & 4.41 & 3.23 \\
\hline & BRI & 3.75 & 2.44 & 1.58 & 2.93 \\
\hline & Others Em. & 10.11 & 15.91 & 8.3 & 11.19 \\
\hline & RoW & 4.34 & 5.91 & 2.31 & 4.29 \\
\hline & All & 100.0 & 100.0 & 100.0 & 100 \\
\hline
\end{tabular}

Note: BRI for Brazil, Russia, India. - Source: BACI, authors’ calculation.

Table A6: Changes in world market shares by transformation level and market segment of manufactured products (1995 to 2004, percentage points). Method with constant shares of quality ranges

\begin{tabular}{|c|c|c|c|c|c|}
\hline Market segment & Exporter & Intermediate goods & Consumer goods & Investment goods & All \\
\hline \multirow{9}{*}{ Lower } & EU 25 & -4.74 & -1.31 & -5.72 & -4.10 \\
\hline & USA & -4.65 & -3.80 & -4.00 & -4.20 \\
\hline & Japan & -1.60 & 0.40 & -4.03 & -1.61 \\
\hline & Oth. devpd & -3.99 & -2.46 & -8.03 & -4.50 \\
\hline & China & 10.00 & 5.76 & 20.54 & 11.24 \\
\hline & BRI & 0.96 & 1.96 & 0.74 & 1.17 \\
\hline & Others Em. & 0.98 & -2.91 & -1.27 & -0.55 \\
\hline & RoW & 3.04 & 2.35 & 1.77 & 2.57 \\
\hline & All & 0.00 & 0.00 & 0.00 & 0.00 \\
\hline \multirow{10}{*}{ Upper } & Upper & Intermediate goods & Consumer goods & Investment goods & All \\
\hline & EU 25 & 0.27 & 0.99 & -1.61 & -0.02 \\
\hline & USA & -2.01 & -1.21 & -7.17 & -2.81 \\
\hline & Japan & -4.10 & -3.61 & -5.48 & -4.23 \\
\hline & Oth. devpd & 0.00 & -4.02 & 3.00 & -0.38 \\
\hline & China & 1.14 & 1.76 & 4.05 & 1.93 \\
\hline & BRI & 1.52 & 0.68 & 1.04 & 1.18 \\
\hline & Others Em. & 2.05 & 3.85 & 5.12 & 3.12 \\
\hline & RoW & 1.13 & 1.56 & 1.06 & 1.20 \\
\hline & All & 0.00 & 0.00 & 0.00 & 0.00 \\
\hline
\end{tabular}

Note: BRI for Brazil, Russia, India. - Source: BACI, authors’ calculation. 
Specialisation across Varieties within Products and North-South Competition

Table A7: World market shares (intra-EU excluded) for standard and Hi-tech manufactured goods, by market segment (1995 and 2004, percent). Method with constant shares of quality ranges

\begin{tabular}{rrrrr}
\hline \hline & \multicolumn{3}{c}{ Standard goods } & HT goods \\
\hline & down-mk & up-mk & down-mk & up-mk \\
\hline Exporter & & & $\mathbf{1 9 9 5}$ & \\
\hline EU 25 & 18.13 & 32.12 & 19.95 & 26.42 \\
USA & 14.60 & 15.42 & 20.75 & 29.45 \\
Japan & 8.02 & 17.73 & 14.30 & 15.33 \\
Oth. Dev & 21.84 & 19.65 & 21.22 & 20.66 \\
China & 9.87 & 1.45 & 7.06 & 0.28 \\
BRI & 5.64 & 1.93 & 1.45 & 0.50 \\
Oth. Em. & 16.09 & 8.31 & 13.61 & 6.40 \\
RoW & 5.82 & 3.39 & 1.65 & 0.97 \\
All & 100 & 100 & 100 & 100 \\
\hline Exporter & & & $\mathbf{2 0 0 4}$ & \\
\hline EU 25 & 14.14 & 32.78 & 14.89 & 24.00 \\
USA & 10.13 & 13.25 & 16.62 & 20.39 \\
Japan & 7.08 & 13.28 & 7.78 & 12.79 \\
Oth. Dev & 17.21 & 18.26 & 17.52 & 25.45 \\
China & 19.48 & 3.17 & 27.43 & 3.52 \\
BRI & 7.07 & 3.25 & 2.12 & 1.21 \\
Oth. Em. & 15.90 & 11.24 & 11.71 & 10.92 \\
RoW & 8.98 & 4.77 & 1.93 & 1.72 \\
All & 100 & 100 & 100 & 100 \\
\hline & & & & \\
\hline \hline
\end{tabular}

Note: See Table 1. High Tech goods are identified at the most detailed level by the Eurostat-OECD list. Source: BACI-CEPII, authors’ calculation. 
Appendix 2: Similarity of export structures at the transformation level (within BEC categories, 1995 and 2004)

\begin{tabular}{lrrrrrrrr}
\hline \hline \multicolumn{1}{c}{ 1995 } & Brazil & China & Japan & Russia & India & USA & EU25 Oth. Em. \\
\hline Brazil &. & & & & & & \\
China & 0.65 &. & & & & & \\
Japan & 0.80 & 0.62 &. & & & & \\
Russia & 0.80 & 0.45 & 0.65 &. & & & \\
India & 0.81 & 0.77 & 0.74 & 0.68 &. & & \\
USA & 0.85 & 0.62 & 0.95 & 0.70 & 0.76 &. & & \\
EU25 & 0.81 & 0.74 & 0.83 & 0.62 & 0.80 & 0.84 & 0.85 & \\
Oth.Em. & 0.72 & 0.76 & 0.63 & 0.59 & 0.81 & 0.64 & 0.73 & 0.71 \\
\hline \hline
\end{tabular}

Source: BACI-CEPII. Authors’ calculations.

\begin{tabular}{lrrrrrrrr}
\hline \hline \multicolumn{1}{c}{ 2004 } & Brazil & China & Japan & Russia & India & USA & EU25 Oth. Em \\
\hline Brazil &. & & & & & & & \\
China & 0.8 &. & & & & & & \\
Japan & 0.91 & 0.84 &. & & & & & \\
Russia & 0.74 & 0.54 & 0.69 &. & & & & \\
India & 0.88 & 0.79 & 0.79 & 0.71 &. & & & \\
USA & 0.92 & 0.78 & 0.94 & 0.76 & 0.81 &. & \\
EU25 & 0.89 & 0.84 & 0.88 & 0.67 & 0.82 & 0.85 & 0.88 & \\
Oth. Em. & 0.77 & 0.71 & 0.71 & 0.65 & 0.78 & 0.7 & 0.76 & 0.7 \\
\hline \hline
\end{tabular}

Source: BACI-CEPII. Authors’ calculations. 


\section{Appendix 3: The CEPII list of emerging countries}

Countries in the CEPII's list of emerging countries have been selected according to two criteria: Per capita GDP of less than half the average of industrialised countries; Rate of export growth at least ten percent higher than the average for industrialised countries. This criteria must be fulfilled either during two of the three sub-periods (1985-90, 1990-95, 1995-2002) or in the latest only (1995-2002).

We obtain a list that includes three members of the EU and Korea. Those four countries are dropped, Korea being considered as an industrialised country. This list could have been updated by taking into account more recent data. However we preferred keeping the original list unchanged, in order to favour comparability with previous work at the CEPII, particularly the CEPII report for the European Commission, DG Trade, 2004, "European Industry Place in the International Division of Labour: Situation and Prospects”, Fontagné L., Fouquin M., Gaulier G., Herzog C., Zignago S.. Furthermore actualising the list would have very little consequences as it would concern small countries.

The Table below gives the share of each emerging country in the total of manufacturing export in 2004. China represents about half the total exports by emerging, while countries as Mozambique, Uganda and Sudan are marginal exporters.

\begin{tabular}{lr}
\hline \hline Country & $\begin{array}{c}\text { Share in emerging countries } \\
\text { manufacturing exports, 2004, percent }\end{array}$ \\
\hline China & 49.4 \\
Malaysia & 9.0 \\
Thailand & 6.8 \\
Brazil & 5.6 \\
India & 5.3 \\
Russia & 4.9 \\
Indonesia & 4.2 \\
Philippines & 3.5 \\
South Africa & 2.7 \\
Argentina & 1.6 \\
Chile & 1.5 \\
Vietnam & 1.3 \\
Pakistan & 1.0 \\
Bangladesh & 0.7 \\
Tunisia & 0.7 \\
Costa Rica & 0.6 \\
Egypt & 0.4 \\
Sri Lanka & 0.4 \\
Ecuador & 0.2 \\
Mauritius & 0.1 \\
Mozambique & 0.1 \\
Uganda & 0.0 \\
Sudan & 0.0 \\
\hline \hline
\end{tabular}


Appendix 4: Explaining bilateral exports in a panel of 163 countries and 10 years (no year fixed effects)

\begin{tabular}{|c|c|c|c|c|}
\hline & $\begin{array}{c}\text { Total trade } \\
\text { Without tariffs } \\
\end{array}$ & $\begin{array}{c}(2) \\
\text { Total trade } \\
\text { With tariffs } \\
\end{array}$ & $\begin{array}{c}(3) \\
\text { Sectoral trade } \\
\text { Without tariffs }\end{array}$ & $\begin{array}{c}(4) \\
\text { Sectoral trade } \\
\text { With tariffs } \\
\end{array}$ \\
\hline \multirow[t]{2}{*}{ Intercept } & -28.04 & -30.62 & -22.42 & -25.43 \\
\hline & $(0.12)$ & $(0.33)$ & $(0.05)$ & $(0.11)$ \\
\hline \multirow[t]{2}{*}{ G1 } & 1.83 & 1.27 & 1.90 & 2.44 \\
\hline & $(0.15)$ & $(0.42)$ & $(0.06)$ & $(0.15)$ \\
\hline G3 & Ref. & Ref. & Ref. & Ref. \\
\hline \multirow{2}{*}{ Distance * low } & -1.09 & -1.115 & -0.79 & -0.74 \\
\hline & $(0.01)$ & $(0.01)$ & $(0.00)$ & $(0.00)$ \\
\hline \multirow[t]{2}{*}{ Distance * high } & -1.06 & -1.10 & -0.73 & -0.67 \\
\hline & $(0.01)$ & $(0.02)$ & $(0.00)$ & $(0.00)$ \\
\hline \multirow[t]{2}{*}{ Common language * low } & 0.78 & 0.79 & 0.56 & 0.60 \\
\hline & $(0.01)$ & $(0.03)$ & $(0.04)$ & $(0.01)$ \\
\hline \multirow[t]{2}{*}{ Common language * high } & 0.95 & 0.89 & 0.65 & 0.67 \\
\hline & $(0.01)$ & $(0.03)$ & $(0.01)$ & $(0.01)$ \\
\hline \multirow[t]{2}{*}{ Exporter GDP } & 0.93 & 0.99 & 0.70 & 0.76 \\
\hline & $(0.00)$ & $(0.00)$ & $(0.00)$ & $(0.00)$ \\
\hline \multirow[t]{2}{*}{ Importer GDP } & 0.72 & 0.72 & 0.57 & 0.58 \\
\hline & $(0.00)$ & $(0.00)$ & $(0.00)$ & $(0.00)$ \\
\hline \multirow[t]{2}{*}{ Exporter GDP per cap. * low } & 0.27 & 0.43 & 0.04 & 0.04 \\
\hline & $(0.01)$ & $(0.02)$ & $(0.00)$ & $(0.01)$ \\
\hline \multirow[t]{2}{*}{ Exporter GDP per cap. * high } & 0.39 & 0.46 & 0.09 & 0.11 \\
\hline & $(0.01)$ & $(0.02)$ & $(0.00)$ & $(0.01)$ \\
\hline \multirow[t]{2}{*}{ Importer GDP per cap. * low } & 0.04 & 0.09 & 0.03 & 0.05 \\
\hline & $(0.01)$ & $(0.02)$ & $(0.00)$ & $(0.01)$ \\
\hline \multirow[t]{2}{*}{ Importer GDP per cap. * high } & 0.14 & 0.21 & 0.16 & 0.22 \\
\hline & $(0.01)$ & $(0.02)$ & $(0.00)$ & $(0.01)$ \\
\hline \multirow[t]{2}{*}{ Tariffs * low } & . & -1.24 & . & -1.53 \\
\hline & . & $(0.21)$ & . & $(0.05)$ \\
\hline \multirow[t]{2}{*}{ Tariffs * high } & . & -1.47 & . & -0.85 \\
\hline & . & $(0.22)$ & . & $(0.05)$ \\
\hline \multirow[t]{2}{*}{ SS * low } & 0.46 & 0.73 & 0.52 & 0.76 \\
\hline & $(0.03)$ & $(0.06)$ & $(0.01)$ & $(0.02)$ \\
\hline \multirow[t]{2}{*}{ SS * high } & -0.44 & -0.47 & -0.63 & -0.43 \\
\hline & $(0.03)$ & $(0.06)$ & $(0.01)$ & $(0.02)$ \\
\hline \multirow[t]{2}{*}{$\mathrm{SN} *$ low } & 0.24 & 0.48 & 0.22 & 0.28 \\
\hline & $(0.02)$ & $(0.06)$ & $(0.01)$ & $(0.02)$ \\
\hline \multirow[t]{2}{*}{$\mathrm{SN} *$ high } & -0.43 & -0.47 & -0.83 & -0.75 \\
\hline & $(0.02)$ & $(0.06)$ & $(0.01)$ & $(0.02)$ \\
\hline \multirow[t]{2}{*}{ NS * low } & -0.10 & 0.12 & -0.05 & 0.30 \\
\hline & $(0.02)$ & $(0.06)$ & $(0.01)$ & $(0.02)$ \\
\hline \multirow[t]{2}{*}{ NS * high } & -0.52 & -0.28 & -0.47 & -0.17 \\
\hline & $(0.02)$ & $(0.06)$ & $(0.01)$ & $(0.02)$ \\
\hline NN & Ref. & Ref. & Ref. & Ref. \\
\hline $\mathrm{R} 2$ & 0.668 & 0.713 & 0.460 & 0.470 \\
\hline Fisher & 33860.2 & 5489.8 & 56777.5 & 12935.2 \\
\hline $\mathrm{P}$ value & $<.0001$ & $<.0001$ & $<.0001$ & $<.0001$ \\
\hline $\mathrm{N}$ & 286,234 & 42,079 & $2,802,011$ & 641,717 \\
\hline
\end{tabular}

Source: BACI-CEPII. Authors' calculations. 
Appendix 5: Distribution of the median elasticity of export prices to GDP per capita of the exporting country (EU imports, 1995 to 2004, Member states considered individually)

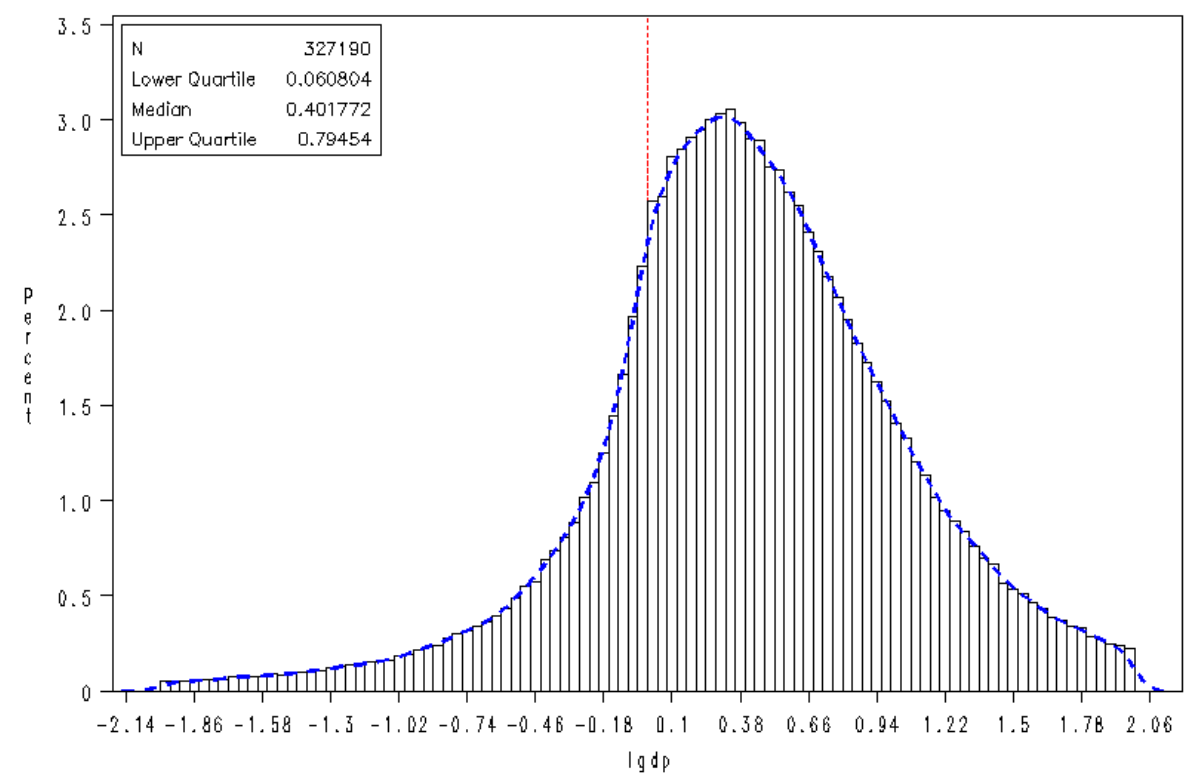

Source: BACI, authors’ estimation using a log linear specification. 
Appendix 6: Distribution of the median elasticity of export prices to GDP per capita of the exporting country

Graph 6-1: EU imports, 1995 to 2004

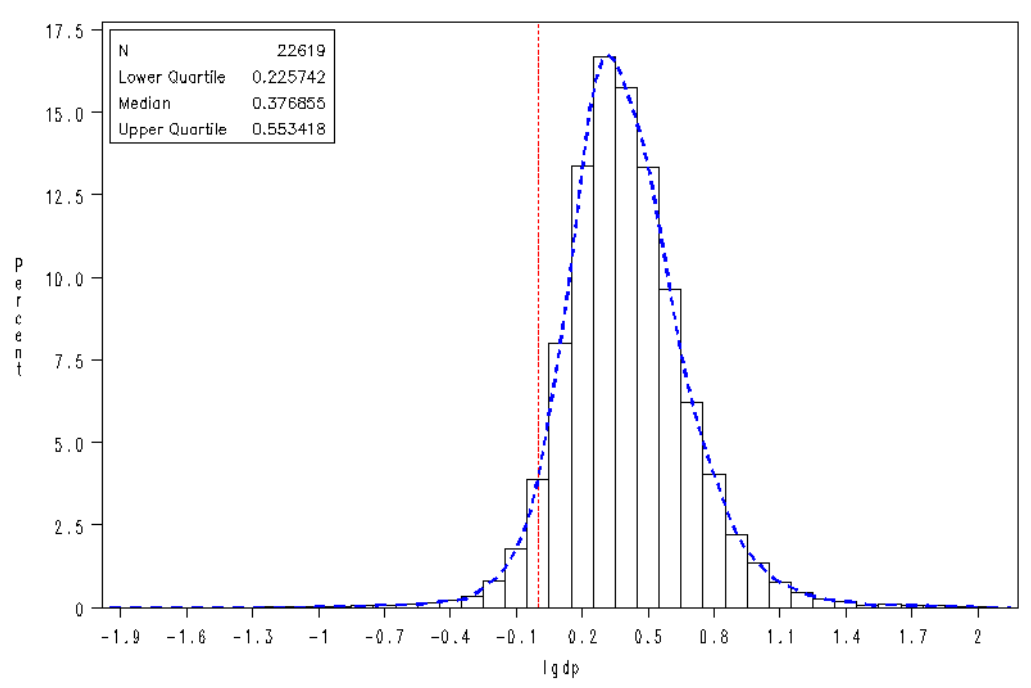

Source: BACI, authors’ estimation using a log linear specification.

\section{Graph 6-2: Japanese imports}

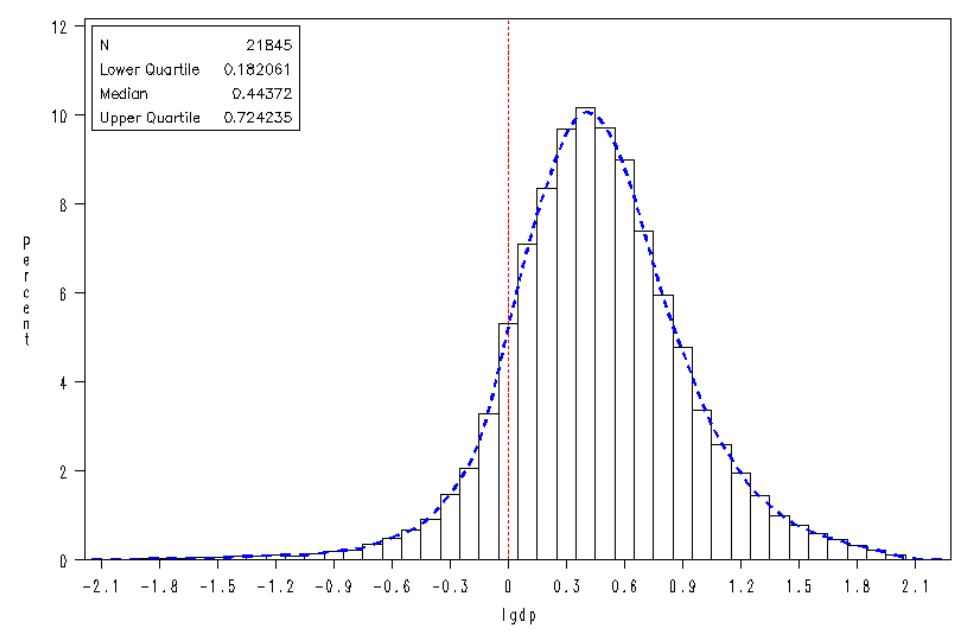

Source: BACI, authors' estimation using a log linear specification. 
Specialisation across Varieties within Products and North-South Competition

Graph 6-3: US imports, 1995 to 2004

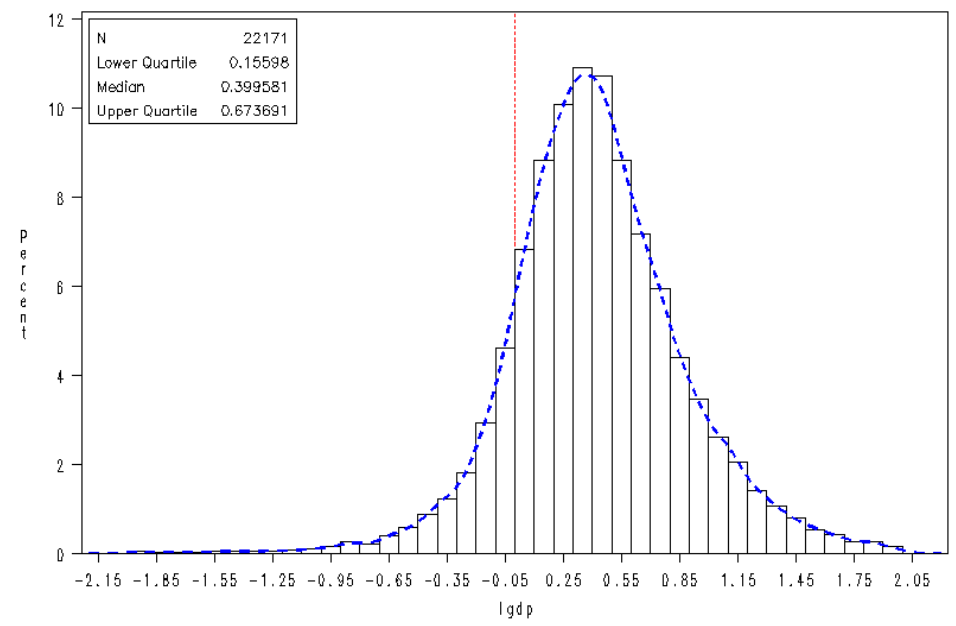

Source: BACI, authors' estimation using a log linear specification. 


\section{LIST OF WORKING PAPERS RELEASED BY CEPII ${ }^{25}$}

No

Title

2007-05 Trade Costs and the Home Market Effect

2007-04 The Impact of Regulations on Agricultural Trade: Evidence from SPS and TBT Agreements

2007-03 International Comparisons of Living Standards by Equivalent Incomes

2007-02 Does Risk Aversion Drive Financial Crises? Testing the Predictive Power of Empirical Indicators

2007-01 Asian Catch Up, World Growth and International Capital Flows in the XXIst Century : A Prospective Analysis with the INGENUE 2 Model

2006-27 Current Account Reversals and Long Term Imbalances: Application to the Central and Eastern European Countries

2006-26 On Legal Origins and Brankruptcy Laws: the European Experience (1808-1914)

2006-25 Taux d'intérêt et marchés boursiers : une analyse empirique de l'intégration financière internationale

2006-24 Changing Patterns of Domestic and Cross-Border Fiscal Policy Multipliers in Europe and the US

2006-23 Market Access Impact on Individual Wage: Evidence from China

2006-22 FDI in Chinese Cities: Spillovers and Impact on Growth
Authors

M. Crozet

\& F. Trionfetti

A.-C. Disdier,

L. Fontagné

\& M. Mimouni

M. Fleurbaey \&

G. Gaulier

V. Coudert \& M. Gex

M. Aglietta, V. Borgy,

J. Château, M. Juillard,

J. Le Cacheux,

G. Le Garrec \&

V. Touzé

K. Benhima

\& O. Havrylchyk

J. Sgard

V. Borgy \& V. Mignon

A. Bénassy-Quéré \& J. Cimadomo

L. Hering \& S. Poncet

N. Madariaga \& S. Poncet

25

Working papers are circulated free of charge as far as stocks are available; thank you to send your request to CEPII, Sylvie Hurion, 9, rue Georges-Pitard, 75015 Paris, or by fax : (33) 0153685504 or by e-mail Hurion@cepii.fr. Also available on: Nwwww.cepii.fr. Working papers with * are out of print. They can nevertheless be consulted and downloaded from this website.

25 Les documents de travail sont diffusés gratuitement sur demande dans la mesure des stocks disponibles. Merci d'adresser votre demande au CEPII, Sylvie Hurion, 9, rue Georges-Pitard, 75015 Paris, ou par fax : (33) 0153685504 ou par e-mail Hurion@cepii.fr. Egalement disponibles sur: Ilwww.cepii.fr. Les documents de travail comportant* sont épuisés. Ils sont toutefois consultable sur le web CEPII. 
2006-21 Taux d'intérêt et marchés boursiers : une analyse empirique de l'intégration financière internationale

2006-20 World Consistent Equilibrium Exchange Rates

2006-19 Institutions and Bilateral Asset Holdings

2006-18 Vertical Production Networks: Evidence from France

2006-17 Import Prices, Variety and the Extensive Margin of Trade

2006-16 The Long Term Growth Prospects of the World Economy: Horizon 2050

2006-15 Economic Integration in Asia: Bilateral Free Trade Agreements Versus Asian Single Market

2006-14 Foreign Direct Investment in China: Reward or Remedy?

2006-13 Short-Term Fiscal Spillovers in a Monetary Union

2006-12 Can Firms' Location Decisions Counteract the Balassa-Samuelson Effect?

2006-11 Who’s Afraid of Tax Competition? Harmless Tax Competition from the New European Member States

2006-10 A Quantitative Assessment of the Outcome of the Doha Development Agenda

2006-09 Disparities in Pension Financing in Europe: Economic and Financial Consequences

2006-08 Base de données CHELEM-BAL du CEPII

2006-07 Deindustrialisation and the Fear of Relocations in the Industry

2006-06 A Dynamic Perspective for the Reform of the Stability and Gowth Pact

2006-05 China's Emergence and the Reorganisation of Trade Flows in Asia

2006-04 Who Pays China's Bank Restructuring Bill?
V. Borgy \& V. Mignon

A. Bénassy-Quéré,

A. Lahrèche-Révil \& V. Mignon

V. Salins

\& A. Bénassy-Quéré

M. Fouquin,

L. Nayman

\& L. Wagner

G. Gaulier \& I. Méjean

S. Poncet

M. H. Bchir \& M. Fouquin

O. Havrylchyk \& S. Poncet

A. Bénassy-Quéré

I. Méjean

A. Lahrèche-Révil

Y. Decreux \& L. Fontagné

J. Château \& X. Chojnicki

H. Boumellassa \& D. Ünal-Kesenci

H. Boulhol

\& L. Fontagné

C. Deubner

G. Gaulier, F. Lemoine \& D. Ünal-Kesenci

G. Ma 


\section{CEPII \\ DOCUMENTS DE TRAVAIL / WORKING PAPERS}

Si vous souhaitez recevoir des Documents de travail, merci de remplir le coupon-réponse ci-joint et de le retourner à :

Should you wish to receive copies of the CEPII's Working papers, just fill the reply card and return it to:

Sylvie HURION - Publications

CEPII - 9, rue Georges-Pitard - 75740 Paris - Fax : (33) 1.53.68.55.04

sylvie.hurion@cepii.fr

M./Mme / Mr./Mrs

Nom-Prénom / Name-First name

Titre / Title.....

Service / Department

Organisme / Organisation

Adresse / Address.

Ville \& CP / City \& post code.

Pays / Country Tél.

Your e-mail

Désire recevoir les Document de travail du CEPII $n^{\circ}$ :

Wish to receive the CEPII's Working Papers No:

Souhaite être placé sur la liste de diffusion permanente (pour les bibliothèques)

Wish to be placed on the standing mailing list (for Libraries). 